\title{
BIOLOGICAL CHARACTERISTICS OF KATAHDIN SHEEP SELECTED FOR FOOTROT RESISTANCE
}

\author{
A Dissertation \\ presented to \\ the Faculty of the Graduate School \\ at the University of Missouri-Columbia \\ In Partial Fulfillment \\ of the Requirements for the Degree \\ Doctor of Philosophy
}

by

SAMANEH AZARPAJOUH

Dr. Tumen Wuliji and Dr. William R. Lamberson, Dissertation Supervisors DECEMBER 2014 
The undersigned, appointed by the dean of the Graduate School, have examined the dissertation entitled

\section{BIOLOGICAL CHARACTERISTICS OF KATAHDIN SHEEP SELECTED FOR FOOTROT RESISTANCE}

presented by Samaneh Azarpajouh,

a candidate for the degree of doctor of philosophy,

and hereby certify that, in their opinion, it is worthy of acceptance.

Dr.Tumen Wuliji

Dr. William Lamberson

Dr. Duane Keisler

Dr. Tim Safranski

Dr. Bruce Shanks

Dr. Heide Schatten 
"Read: In the name of your Lord who created. Who created man from a clinging entity. Read! Your Lord is the most Noble, Who taught by the pen. Who taught man what he did not know." (Qur'an, 96:1-5)

"Call to me and I will answer you, and will tell you great and hidden things that you have not known." (Jeremiah 33:3)

"How great are your works, O Lord, how deep are your thoughts." (Psalms 92:6)

To my beloved family who taught me human excellence is in seeking the truth. 


\section{ACKNOWLEDGEMENT}

There are many people that have played an important role over the past several years in helping me reach this point in life. While it is impossible to thank everyone, I would like to express my appreciation to several individuals for their assistance and guidance. I would like to gratefully and sincerely thank my graduate committee, Dr. Tumen Wuliji, Dr. William Lamberson, Dr. Duane Keisler, Dr. Tim Safranski, Dr. Bruce Shanks, and Dr. Heide Schatten for their guidance, patience, knowledge and support throughout my graduate experience. I would like to thank USDA and Lincoln University of Missouri for providing the source of funding for this research project. A special thanks goes to Lincoln University George Washington Carver Farm, Lincoln University of New Zealand and Electron Microscopy Core staff at University of Missouri - Columbia for their assistance to collect data. I must mention Lincoln University Cooperative Research faculty and staff, all the faculty and graduate students at Division of Animal Science, University of Missouri -Columbia for their friendships and assistance.

I would like to express my deepest gratitude to Dr. Ahmadreza Mohamdnia, Dr. Marzieh Mehdizadeh, Dr. Charlotte Clifford-Rathert, Amy Bax, Heather Hilsenbeck, Cindy Thompson, Cindy Borgwordt, and Luke Wilber for their friendship and assistance in all aspects of my program. I have been far from my family in Iran, but have been fortunate to be part of Farley, Rollins and Kaplan families. Thank you for your love and support. The work presented in this dissertation would not have been possible without each and every one of you. Thank you. 


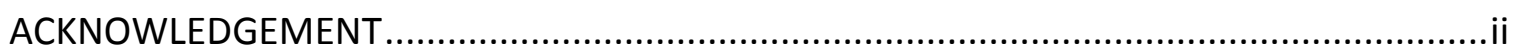

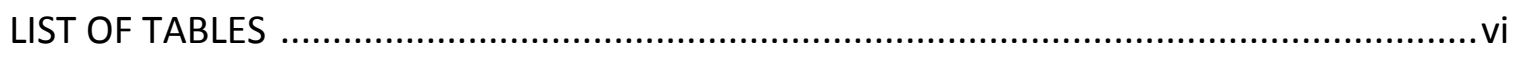

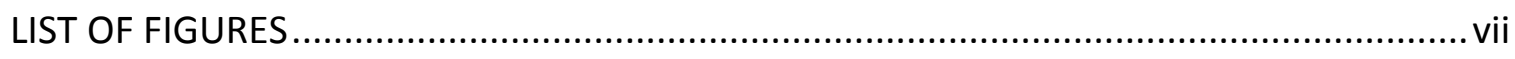

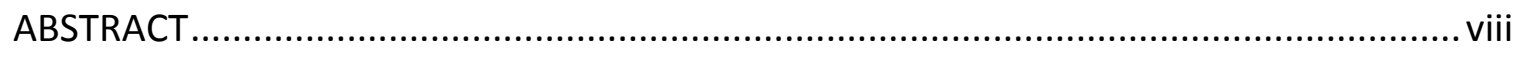

Chapter

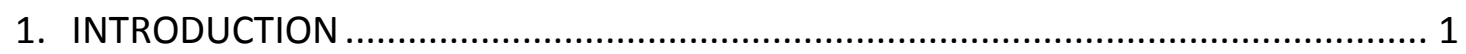

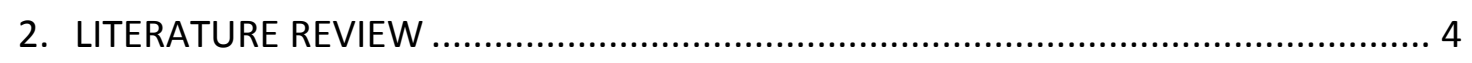

a. Genetics of disease resistance...................................................................

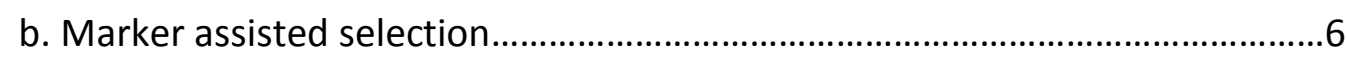

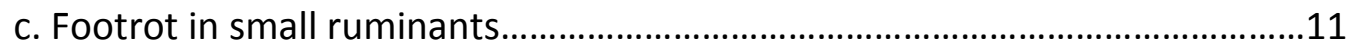

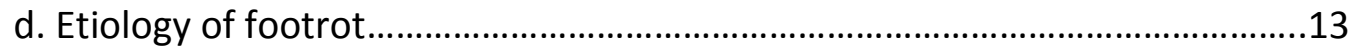

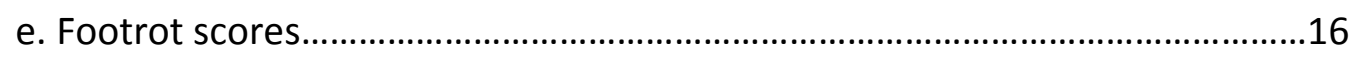

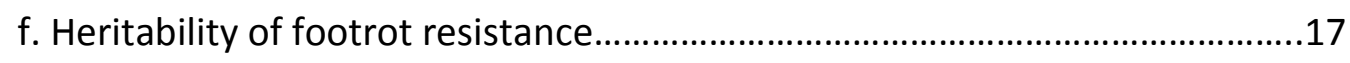

g. Phenotypic and genetic variation in footrot resistance.................................19

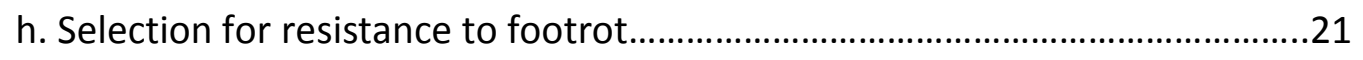

i. Phenotypic and genetic assessment for resistance to footrot........................23

j. Footrot gene-marker screening test.........................................................24 
3. COMPARISON OF SELECTED RESISTANT AND SUSCEPTIBLE KATAHDIN SHEEP TO

a. Abstract. .26

b. Introduction .28

c. Materials and methods. 30

i. Footrot gene marker test (FGMT) screening...... 30

ii. Footrot lesion scoring, swabbing and bacteria inoculants preparation 31

iii. Footrot bacteria inoculants preparation .32

iv. Bacteria D. nodosus protease thermostability determination. .33

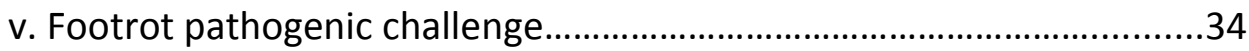

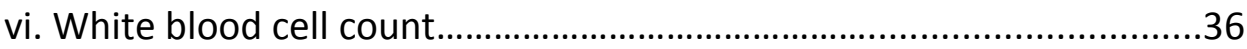

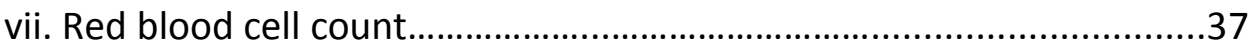

viii. Packed cell volume (PCV) measurement..........................................37

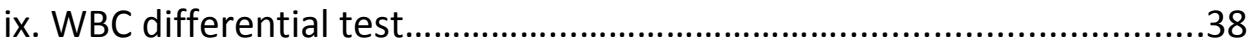

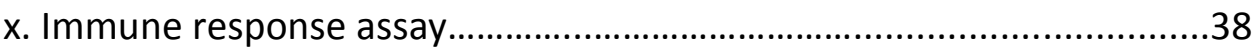

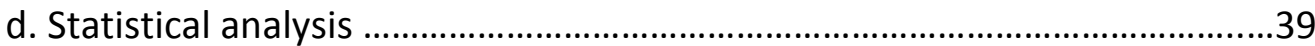

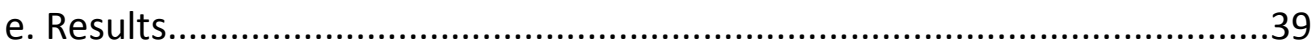

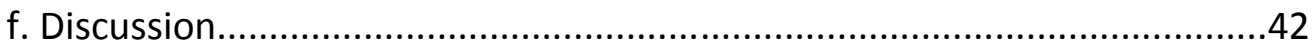

4. COMPARISON OF WHITE BLOOD CELL PHAGOCYTIC EFFICIENCY IN FOOTROT RESISTANT VS. SUSCEPTIBLE GENOTYPES OF KATAHDIN SHEEP ....................55 


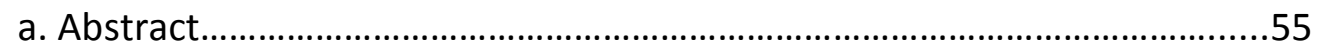

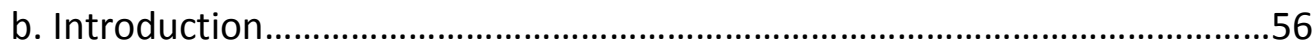

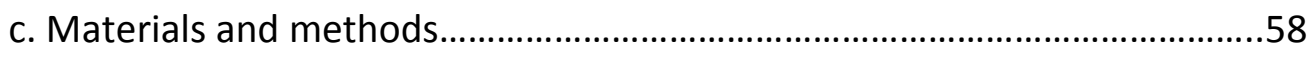

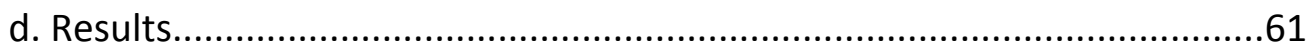

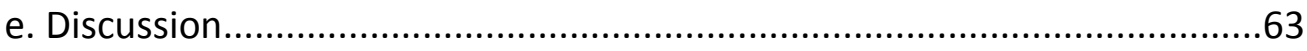

\section{COMPARISON OF ULTRASTRUCTURAL CHANGES CAUSED BY DICHELOBACTER} NODOSUS IN STRATUM CORNEUM OF HOOF TISSUE OF SHEEP ....................71

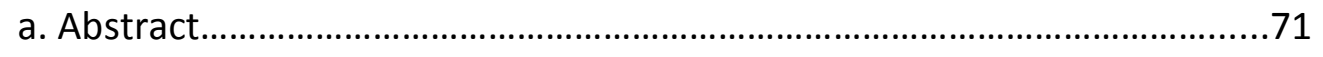

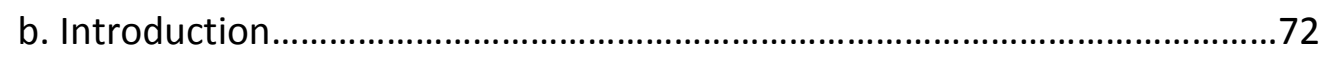

c. Materials and methods............................................................................

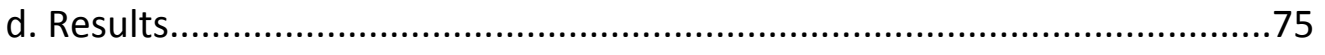

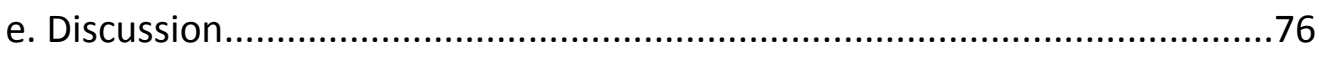

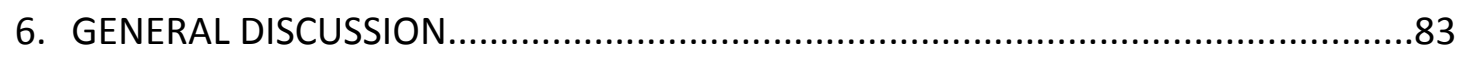

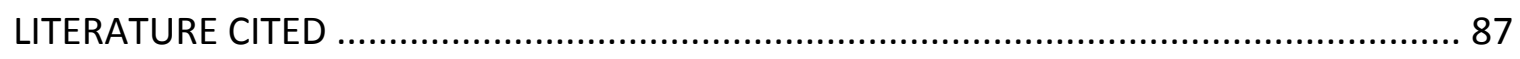

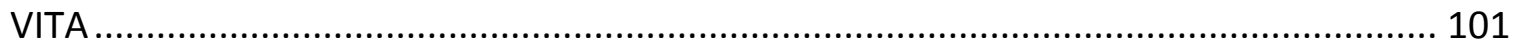




\section{LIST OF TABLES}

\section{Table}

1. Footrot scores by hoof color, gene marker (low, medium and high resistance) and breed in treatment (D) group.................................................................. 52

2. Average RBC count, WBC count, and $P C V$ in $C$ and $D$ groups at the beginning (CB and $D B$ ) and the end of trial (CE and DE)

3. WBC differential count in $C$ and $D$ groups at the beginning ( $C B$ and $D B$ ) and the end of trial (CE and DE) 


\section{LIST OF FIGURES}

Figure

Page

1. Comparison of average body condition score at the beginning (BCS1) and the end (BCS2) of trial between control (C) and treatment(D) groups 46

2. Comparison of average body weight at the beginning (WT1) and the end (WT2) of trial between control (C) and treatment (D) groups

3. Comparison of IgG level in sera between control (C) and treatment (D) groups ... 48

4. Clear zones of proteolysis around inoculated wells with $D$. nodosus in the gelatin test before incubation

5. Clear zones of proteolysis around inoculated wells with $D$. nodosus in the gelatin test 8 min incubation............................................................................... 50

6. Clear zones of proteolysis around inoculated wells with $D$. nodosus in the gelatin test 16 min incubation

7. Comparison of the numbers of bacterial colonies after addition of neutrophils and incubation periods in the low resistant gene marker group vs. the high resistant gene marker group

8. Comparison of the numbers of bacterial colonies after addition of neutrophils and incubation periods in ewes vs. rams

9. Comparison of the number of bacterial colonies after addition of neutrophils and after 20,40, and 60 min of incubation

10. Normal hoof structure in control samples

11. Colonies of rod shaped $D$. nodosus with type IV fimbriae

12. Black hoof tissue invaded by $D$. nodosus 81

13. White hoof tissue invaded by $D$. nodosus 


\section{BIOLOGICAL CHARACTERISTICS OF KATAHDIN SHEEP SELECTED FOR FOOTROT RESISTANCE Samaneh Azarpajouh}

\section{Dr. Tumen Wuliji and Dr.William R. Lamberson, Dissertation Supervisors}

ABSTRACT

The objectives of this study were to select sheep divergent for a footrot resistant genotype by screening with the DQA2 gene marker and to investigate the host resistant immune response, neutrophil phagocytic efficiency, and damage caused by pathogenic bacteria in stratum corneum of hoof tissue. Sixty-eight Katahdin and Katahdin x Dorper crossbred ewes were stratified by body weight and footrot gene marker test scores into control (C) and treatment (D) groups. Cultures of $D$. nodosus were inoculated to the inter-digital skin of the treatment group. White and red blood cell count, packed cell volume, WBC differential, immune response measurements, body weight, body condition scores, and footrot scores were recorded. The protease thermostability of $D$. nodosus was tested by using a gelatin test. Neutrophil phagocytic efficiency was tested in different marker groups. Damage caused by $D$. nodosus on white and black hoof tissue samples was observed by an Environmental Scanning Electron Microscope. The data were analyzed by using mixed model procedures of SAS, and $P<0.05$ was considered as significant. At the end of trial, $C$ group had a footrot score of 0 , but D group had footrot scores of 0 to 2 . The $\lg G$ level in sera $(\mathrm{mg} / \mathrm{ml})$ was greater in $D$ than $C$ groups $(P<0.0001)$. The neutrophils in high resistant genotypes of sheep had significantly more efficient phagocytic activity vs. low resistant genotypes. Sinus formation was observed in both white and black hoof tissues, but there was no relationship between the tissue pigment and the ultrastractural changes in tissue. The gelatin test determined the enzyme activity of inoculated $D$. nodosus and since no virulent cases of footrot were observed during footrot pathogenic challenge, it can be used as evidence of footrot resistance in the Katahdin sheep breed. 


\section{CHAPTER I}

\section{INTRODUCTION}

Footrot (Inter-digital Necrobacillosis) is a highly contagious disease affecting the feet of hoofed animals and has significant economic and animal welfare impacts on the small ruminant livestock industry. Despite its worldwide presence, the largest economic impact has been seen in those countries with moderate to high rainfall (Stewart, 1989). Footrot is a wide spread problem on sheep farms and is responsible for $10 \%$ production losses in body weight and wool growth in affected animals, in addition to increased treatment and control costs (Stewart et al., 1984; Marshall et al., 1991; Glynn, 1993).

Footrot in sheep and goats is caused mainly by infection with bacteria Dichelobacter nodosus (D. nodosus) and Fusobacterium necrophorum (F. necrophorum). D. nodosus is the causative agent of ovine footrot. F. necrophorum which exists in the rumen flora and is shed in the feces usually initiates bacterial invasion of predisposed inter-digital skin between toes. When both $D$. nodosus and $F$. necrophorum are present in the same environment, they invade the epidermal matrix together (Egerton et al., 
1969). The infection is largely specific to sheep and goats, although it has also been reported in other species including cattle, horses, pigs, deer, and mouflon (Beveridge, 1967; Ghimire et al., 2002).

Some heritable host factors, environmental conditions, nutrition, foot shape, structure, and age (generally younger animals are more susceptible) determine whether or not animals are susceptible to footrot (Raadsma et al., 1994a). The severity of footrot depends on an interaction of the environmental, bacterial, and host factors involved in different outbreaks. In groups of small ruminants in the same environment, there will be animals which are highly susceptible, partly susceptible, or resistant (Egerton, 2002).

Sheep and goats are becoming a major alternative to cattle for diversified small farm enterprises because of advantages including small body size, being easy to handle, higher prolificacy, shorter gestation length, and earlier maturity compared to cattle. Considering the estimated annual cost of footrot, $\$ 18.5 \mathrm{M}$ in Australia (Sacket et al., 2006) and $£ 24 M$ in Great Britain (Nieuwhof and Bishop, 2005), prevention is beneficial compared to treating the disease. Many producers spend time and money every year to control the disease. Moreover, the disease is more prevalent in areas with a mean daily temperature above $10^{\circ} \mathrm{C}$ following two to three months of rainfall exceeding about 50 mm per month, similar to Midwest U.S. environmental conditions. It is well known that for many diseases, resistance has a genetic component and selection for disease resistance has long been considered a promising way to reduce disease prevalence (Nieuwhof et al., 2009); however, there is little information available on footrot 
resistance heritabilities and response to selection in small ruminants in the United States.

Genetic markers can be used to classify susceptible or resistant animals without subjecting them to a pathogenic challenge and can shorten the generation interval (Collins and Conington, 2005). Additionally, establishment of a footrot resistant sheep flock by using marker assisted selection enables farmers and producers to control and eradicate the disease, improve animal health and welfare and produce safe, high-quality food (Wuliji et al., 2013b, Wuliji et al., 2014).

\section{Objectives}

The objectives of this study were:

1) To select sheep divergent for a footrot resistant genotype by screening with the DQA2 gene marker;

2) To identify the footrot pathogenic bacteria thermostability and investigate the host resistant immune response (antibody);

3) To investigate white blood cell phagocytic efficiency in sheep with a footrot resistant vs. susceptible genotype;

4) To compare damage caused by pathogenic bacteria in stratum corneum of hoof tissue of sheep. 


\section{CHAPTER II}

\section{LITERATURE REVIEW}

\section{Genetics of disease resistance}

Infectious diseases affect animals' health, welfare, production, and the quality of food resources and despite all the traditional disease controlling systems, they continue to impede the livestock industry (Adams and Templeton, 1998). A number of approaches such as vaccination, the control of disease vectors, and appropriate management methods to reduce these negative effects. However, there are often constraints to the sustainability of such disease control strategies like environmental and food safety-related impacts of chemical treatments, the affordability and accessibility of treatments to poorer livestock producers, and the evolution of parasite resistance to the treatments (BOA, 1999).

Considering the economic impacts, health and welfare issues of infectious diseases on the livestock industry, prevention has more advantages than curing a disease. Different environmental and host factors, some metabolic diseases, host 
immune status, pregnancy or lactation can affect animals' resistance to infectious disease; for example several epidemiological studies have demonstrated there is an association between the development of metabolic disease and subsequent development of mastitis (Curtis et al., 1983).

Genetic disease resistance involving immune and non-immune mechanisms is an approach to this problem (Adams and Templeton, 1998). Disease resistance is the inherent capacity of a previously unexposed animal to resist disease when challenged by pathogens and is considered as the host's ability to moderate the pathogen or parasite lifecycle, and also resistance to the disease consequence of infection (Adams and Templeton, 1998, Bishop and Morris, 2007). Natural resistance is heritable and transmissible from parent to offspring; therefore, increasing the overall level of genetic resistance of a population by using selective breeding programs can improve animal health management systems (Adams and Templeton, 1998).

The advantages of incorporating genetic elements in disease management strategies include: the permanence of genetic change once it is established; the consistency of the effect; the absence of the need for purchased inputs once the effect is established; the effectiveness of other methods is prolonged as there is less pressure for the emergence of resistance; the possibility of broad spectrum effects and increasing resistance to more than one disease; the possibility of having less impact on the evolution of macro-parasites such as helminthes compared to other strategies such as 
chemotherapy or vaccination; and adding to the diversity of disease management strategies (FAO, 1999).

Applying different strategies to the genetic management of disease depends on the nature of the problem and the resources available. These approaches include choosing the appropriate breed for the production environment, cross-breeding to introduce genes into breeds that are otherwise well-adapted to the required purposes, and selection for individuals that have high levels of disease resistance (FAO, 2007). There are breeding programs focused on selecting commercial animals for enhanced resistance to some diseases including nematode parasite infections, some forms of mycotoxin poisoning, mastitis, footrot, and scrapie. Finding genetic markers associated with resistance to infection potentially allows selection for increased resistance in the absence of infection (Bishop and Morris, 2007).

\section{Marker Assisted Selection}

Marker Assisted Selection (MAS) is a process in which a morphological, biochemical, or DNA/RNA-based marker is used for indirect selection of a trait of interest (e.g. productivity, disease resistance; Ribaut et al., 2001). The term MAS was first used by Beckmann and Soller (1986) and involves selecting individuals based on their marker pattern (genotype) rather than their observable traits (phenotype; Boopathi, 2013). 
The marker used for selection is associated at high frequency with the gene or Quantitative Trait Locus (QTL) of interest due to genetic linkage. Quantitative Trait Loci are stretches of DNA containing or linked to the genes that underlie a quantitative trait (Gelderman, 1975). There are selectable markers which eliminate certain genotypes from the population and screenable markers which cause certain genotypes to be readily identifiable, at which point the experimenter must score or evaluate the population and act to retain the preferred genotypes. Most MAS uses screenable markers rather than selectable markers (Ribaut and Hoisington, 1998).

Using a MAS program allows recessive alleles to be identified by appropriate linked markers. When multiple resistance genes are combined together in the same variety or breeding line, the presence of one resistance gene may conceal the effect of additional genes. This problem can be overcome if markers are available for each of the resistance genes. If a reliable marker for a low heritable trait is available, MAS can result in greater progress than phenotypic selection. Marker Assisted Selection may be cheaper and faster than conventional phenotypic assays, depending on the trait. Multiple markers can be evaluated using the same DNA sample, and once DNA is extracted and purified, it may be used for multiple markers, for the same or different traits, thus reducing the time and cost per marker (Boopathi, 2013).

There are different types of markers. Morphological markers are often detectable by simple visual inspection. Biochemical markers are proteins that can be extracted and observed. Cytological markers are the chromosomal bandings produced 
by different strains. DNA-based markers (molecular or genetic) are unique genes or DNA sequences, with a known location on a chromosome, that can be used to identify species. Genetic markers can be identified by a range of molecular techniques such as microsatellites or single nucleotide polymorphism (SNP) detection. Linked markers are molecular markers located very close to major genes of interest. They are only near the gene of interest on the chromosome and are not part of the DNA of the gene of interest. Direct markers are part of the gene of interest. Direct markers are easier to work with after they are found, but they often are more difficult to find than linked markers (Ribaut and Hoisington, 1998). There are several phenotypic and genetic markers for nematode resistance in sheep naturally infected with nematodes that could potentially assist response to selection. The phenotypic physiological markers include immunoglobulin A (IgA) activity (Strain et al., 2002), pepsinogenaemia (Stear et al., 1999), fructosamine concentrations in the plasma (Stear et al., 2001) and eosinophilia (Stear et al., 2002). The genetic markers include the Major Histocompatibility Complex (MHC; Schwaiger et al., 1995, Stear et al., 2005) and the interferon gamma region (Coltman et al., 2001). Quantitative Trait Loci for IgA produced in response to Strongyles challenge have been reported by Davies et al. (2006) on chromosomes 3, in the interferon gamma region, and 20, in the MHC region. The study by Cockett et al. (2005) also found a QTL for packed red blood cell volume (PCV) after Haemonchus contortus challenge in the same location on chromosome 1 as the Fecal Egg Count (FEC) QTL. 
With the advent of DNA-based genetic markers in the late 1970s, researchers began to identify large numbers of markers dispersed throughout the genetic material of any species of interest and used the markers to detect associations with traits of interest, thus allowing MAS to finally become a reality (Guimarães, 2007). NeimannSorensen and Robertson (1961) and Smith (1967) explained the basic theory for incorporating specific loci with direct effects on a quantitative character into a selection index. The advances made in the application of molecular genetics and in the identification of loci and chromosomal regions containing loci affecting traits of interest in livestock production improved the genetic programs using direct selection on genes or genomic regions affecting economic traits through MAS and gene introgression (Andersson, 2001; Dekkers and Hospital, 2002).

Gene or QTL mapping using different techniques is the first step for MAS. Quantitative Trait Loci analysis is a statistical method linking phenotypic data (trait measurements) and genotypic data (usually molecular markers) to explain the genetic basis of variation in complex traits (Falconer and Mackay, 1996; Kearsey, 1998; Lynch and Walsh, 1998).

To begin a QTL analysis, two or more strains of organisms that differ genetically with regard to the trait of interest and genetic markers that distinguish between these parental lines are required. Molecular markers are preferred for genotyping, because they are unlikely to affect the trait of interest. Several types of markers are used, including single nucleotide polymorphisms (SNPs), simple sequence repeats (SSRs, or 
microsatellites), restriction fragment length polymorphisms (RFLPs), and transposable element positions. Generally, the markers to be used should be close to the gene of interest $(<5$ recombination unit or $\mathrm{cM}$ ) in order to ensure that only minor fraction of the selected individuals will be recombinants. Preferably two markers are used to reduce the chances of an error due to homologous recombination (Casa et al., 2000; Vignal et al., 2002; Gupta and Rustgi, 2004; Henry, 2006).

Quantitative Trait Loci analysis is carried out by crossing the parental strains which results in heterozygous (F1) individuals, and these individuals are then crossed. The phenotypes and genotypes of the derived (F2) population are scored, and markers that are genetically linked to a QTL influencing the trait of interest will segregate more frequently with trait values, whereas unlinked markers will not show significant association with phenotype (Darvasi, 1998). However, there are some limitations of QTL analysis including requiring very large sample only those differences captured between the initial parental strains can be mapped. Because these strains are unlikely to contain segregating alleles of large effect at every locus contributing to variation in natural populations, some loci will remain undetected, and the specific alleles that segregate, particularly in inbred lines, may not be relevant to natural populations. Therefore, the goal for many studies is to identify loci rather than particular alleles, but the notable area of exception involves applied studies in medicine and agriculture, which are often interested in specific segregating alleles (Miles and Wayne, 2008). 


\section{Footrot in small ruminants}

Footrot is a mixed bacterial infection and a highly contagious disease, particularly in sheep, goats, cattle and some wild ungulates (Raadsma and Dhungyel, 2013). It is a subacute or acute necrotic infection originating from a lesion in the interdigital skin that leads to cellulitis in the digital region and is also known as Inter-digital Necrobacillosis (Black's Veterinary Dictionary, 1995). The disease begins as an interdigital dermatitis that can extend into the adjacent hard horn tissue of animal hooves. Small ruminant livestock, such as sheep and goats, are especially vulnerable in hot, humid, and rainy environments (Bulgin et al., 1988).

Footrot is an important disease in temperate climates caused by infection with the bacterium Dichelobacter nodosus in association with other bacteria, particularly Fusobacterium necrophorum (Egerton et al., 1969; Roberts and Egerton, 1969). Although other environmental bacteria, including Spirochaet apenortha subsequently invade the primary lesions (Beveridge, 1935), D. nodosus is the essential transmitting agent of footrot, and in its absence lesions of footrot do not develop.

Environmental and host factors play an essential role in the initiation and development of the disease (Beveridge, 1934; Graham and Egerton, 1968). It seems that a temperature above $10^{\circ} \mathrm{C}$ is required for footrot transmission to occur, and consistent rainfall over several weeks is required for a footrot outbreak. It has been proposed that wet weather affects footrot susceptibility, either by inducing physical changes in the 
hoof that make it more vulnerable to attack, or by changing the biology of the pathogens that cause footrot (Graham and Egerton, 1968).

Virulent footrot can cause poor feed intake, severe production losses in sheep and goats, severe economic losses, suffering due to lameness, disruption of normal farm operations, death from a combination of starvation, thirst, and systemic bacterial infections that occur in sheep that spend prolonged periods recumbent (Stewart, 1989). Economic losses are due to reduced body weight and growth, decreased wool production and restrictions to marketing opportunities. Many producers lose time and money each year in an attempt to control the disease in their flock or herd. If footrot becomes a problem, it takes much effort and labor to control symptoms and eliminate it. The estimated annual cost of virulent footrot in $2005-2006$ for Australia was $\$ 18.5 \mathrm{M}$ (Sacket et al., 2006), and for Great Britain was f24M (Nieuwhof and Bishop, 2005). Footrot has a wide range of virulence and it has been categorized as virulent, intermediate and benign. Benign footrot may also be known as foot scald in which the infection is confined largely to the inter-digital skin, with only minimal under-running of the adjacent horn. Benign footrot causes inflammation of the inter-digital skin with inter-digital dermatitis, but no under-running or delamination is observed. Clinically, benign footrot appears similar to ovine inter-digital dermatitis, but $D$. nodosus is involved. The economic effect of benign footrot is much less than that of virulent footrot (Glynn, 1993). 
Intermediate footrot can cause under-running in some animals and even in favorable environmental conditions it is much less widespread and transmittable within a flock. It can be diagnosed by the isolation and identification of $D$. nodosus strains with intermediate virulence factors (Stewart et al., 1986).

Virulent footrot displays the destruction of the horn and erosion of the skin-horn junction that penetrates the hoof, causing delamination due to under-running (Stewart et al., 1986). It is a chronic necrotizing lesion of the epidermis of the inter-digital skin and hoof matrix which begins as an inter-digital dermatitis and extends to the large areas of the hoof matrix. In virulent footrot the sensitive lamina and its network of capillaries are destroyed by the infection; therefore, the hoof wall corium loses its blood supply and anchorage to the underlying tissue and becomes detached (Stewart, 1989).

\section{Etiology of footrot}

Dichelobacter nodosus, formerly known as Bacteroides nodosus, is a pathogenic, anaerobic, non-spore-forming gram-negative bacterium (Beveridge, 1941). D.

nodosus can be described as a large rod with terminal swellings with long polar fimbriae. Based on the surface antigen (K), now found to be identical with the fimbriae, $D$. nodosus strains have been classified into 10 serogroups $(A-I, M)$ and 18 serotypes (Wani and Samanta, 2005).

D. nodosus has several virulence factors such as fimbriae, proteases, and outer membrane proteins. The fimbriae of $D$. nodosus are required for binding to epithelial 
cells, providing twitching motility and thermostable proteases contributing to the pathogenesis of $D$. nodosus. In contrast with the proteases of $D$. nodosus, outermembrane proteins of this bacterium are not known to play a direct role in attacking the host; but they interfere with host immune response because they are highly antigenic and phase-variant as a result of site-specific inversions within the outer membrane protein genes. This phase variance is likely to allow populations of $D$. nodosus to undergo antigenic shifts and evade the immune system during the course of an infection (Myers et al., 2007).

Fusobacterium necrophorum, a gram-negative anaerobic bacterium, is a normal inhabitant of gastrointestinal tracts of ruminants and can normally be found in manure contaminated environments. It is responsible for lameness and foot scald in sheep, Lemierre's syndrome, and $10 \%$ of all acute sore throats (Aliyu et al., 2004). It can last for several years on land used by either sheep or cattle. Breakage or weakness of the skin surrounding the hoof due to strong footbaths, sandy soils, mild frostbite, or prolonged water logging of a field can cause foot scald.

Under favorable environmental conditions (the mean daily temperature above $10^{\circ} \mathrm{C}$ following two to three months of rainfall exceeding about $50 \mathrm{~mm}$ per month), $F$. necrophorum colonizes the moist, macerated inter-digital skin and provides ideal conditions for invasion by D. nodosus at the skin/hoof interface (Abbott and Lewis, 2005). By action of proteases, $D$. nodosus liquefies the cells of the stratum granulosum and stratum spinosum, causing separation of the hoof wall from the basal epithelium 
and then it works its way down the inter-digital horn to the heel, then to the sole, and finally to the lateral side of the hoof. There are at least 20 different strains of $D$. nodosus, with varying pathogenicity. Transmission occurs most rapidly in warm and moist conditions; however, cold moist conditions are also conducive to transmission (The Merck Veterinary Manual, 2013).

D. nodosus cannot survive longer than a few days outside the feet of ruminants (Beveridge, 1941; Laing and Egerton, 1981), and the strains of D. nodosus which cause virulent footrot do not readily establish persistent sub-clinical or latent infections (Thomas, 1957). These two factors make eradication of the disease from flocks possible (Egerton and Raadsma, 1993). By contrast, strains of $D$. nodosus which cause the milder forms of footrot (including benign footrot) may persist in the stratum corneum, with no clinically detectable lesion, for prolonged periods (Egerton and Parsonson, 1969; Glynn, 1993; Depiazzi et al., 1998).

F. necrophorum produces a leukocidal exotoxin that reduces phagocytosis and causes suppurative necrosis. D. nodosus produces an enzyme capable of digesting the connective tissue of the hoof horn, thereby allowing migration to areas under the horn. If footrot is not controlled, it may invade deeper structures of the foot, including joints which may lead to septic arthritis (Egerton, 1989). Both F. necrophorum and D. nodosus are essential for the invasion of the epidermal matrix of the hoof and neither bacterial species alone will cause a footrot lesion (Egerton et al., 1969; Roberts and Egerton, 1969). 
New footrot infections always commence in the inter-digital skin and advanced infections frequently involve the sole and hoof wall. The inter-digital skin is normally resistant to bacterial infection and is only susceptible if it is predisposed by prolonged exposure to wet conditions, leading to maceration and devitalisation (Beveridge, 1934). Following the development of the inter-digital lesion, footrot infection may extend into the sensitive laminae underlying the sole, which then progressively separates from the foot (Gregory, 1939; Deane and Jensen, 1955).

\section{Footrot scores}

Footrot scores are used to grade footrot lesions. Egerton and Roberts (1971) used a 5-scale (0-4) scoring system. Score 0 represents a normal hoof with no signs of any foot lesion, infection or irritation. With score 1 there is mild inter-digital dermatitis or scald with some loss of hair and light to moderate inflammation confined to the interdigital skin and it may involve erosion of epithelium. With score 2 there is more extensive inter-digital dermatitis and necrotizing inflammation of inter-digital skin. Score 3 shows the foot with severe inter-digital dermatitis and under-running of the horn of the heel and sole and in score 4 there is severe inter-digital dermatitis and underrunning of the horn of the heel and sole extending towards the walls of the hoof.

This system was modified by Stewart et al. (1982), and score 3 lesions were subdivided into $3 a, 3 b$ and $3 c$ according to the degree of under-running. Score $3 a$ 
represents separation of the skin horn junction, with under-running extending no more than $5 \mathrm{~mm}$. In score $3 \mathrm{~b}$ there is under-running no more than halfway across the heel or sole, and in score $3 c$ there is more extensive under-running of the heel or sole but not extending to the outside edge of the sole of the claw.

A sheep is classified as affected with footrot when it has a lesion with a score $>2$ (Marshall et al., 1991), or a lesion with a score $\geq 3$ a in at least one foot or a score of 2 in at least two feet (Egerton et al., 1979, Egerton and Thorley, 1981), or when there is a lesion with a score of 1 present (Woolaston, 1993).

\section{Heritability of footrot resistance}

Breed differences in susceptibility to footrot have long been recognized and confirmed when animals of different breeds were uniformly exposed to infection by experimental and field challenges (Skerman et al., 1982; Emery et al., 1984; Stewart et al., 1985; Cumlivski, 1988; Lewis et al., 1988). Emery et al. (1984) found that British breeds were more resistant to footrot than Merinos under a moderate challenge on pasture (as expressed in lower severity, rather than fewer feet affected), but not when cultures of $D$. nodosus were applied directly to each hoof. Burke and Parker (2007) found breed differences among various hair breeds, hair breed crosses, and Dorset sheep in the number of locations on a hoof affected by footrot and odor, but not footrot severity (score) or consequent culling. 
There are strong indications that within breeds, disposition to footrot infection is responsive to selection. Comparing offspring from different Targhee rams, Bulgin et al. (1988) concluded that susceptibility to footrot is heritable, without presenting a heritability estimate. In the USA, Parker et al. (1983) reported significantly improved footrot resistance in progeny of Targhee sheep which had failed to succumb to a preliminary artificial challenge. In New Zealand, similar advantages have been demonstrated in the Broomfield strain of Corridale sheep developed from animals that have endured intensive field exposure to the disease (Skerman and Moorhouse, 1987).

Estimates for the heritability of footrot susceptibility vary. From an investigation of straightbred Romney and Perendale ewes and their Booroola Merino crosses, Baker et al. (1986) reported estimates of 0.34 for susceptibility to mild footrot and 0.03 for susceptibility to severe footrot. Heritabilites of 0.53 and 0.23 , respectively, were reported by Alwan (1983) for the same traits in Perendale sheep, and for the Romney breed, Skerman et al. (1988) reported heritabilities of 0.28 and 0.17 . In a genetic study following a challenge and subsequent vaccination, Raadsma et al. (1994b), working with Merino sheep, found heritability estimates of susceptibility to footrot to range between 0.09 and 0.41 , depending on the time when the inspections were made after challenge. Half-sib heritability estimates of resistance to footrot were low to moderate for single observations recorded pre-vaccination (0.07-0.22) and slightly lower for inspections made after vaccination (0.07-0.15). In a lamb population with a prevalence of footrot ranging from $1 \%$ to $34 \%$ in females and $31 \%$ to $57 \%$ in males, Skerman et al. (1988) 
calculated a heritability of 0.17 on the underlying scale for the binary trait (i.e. presence or absence of footrot) in Romney lambs 8 to 9 months of age. In the same dataset, the heritability of overall score, an assessment of footrot severity on a continuous scale, was 0.14. The heritability estimated in an offspring regression for the binary trait scored at about the same time was similar $(0.12)$, suggesting that the trait in lambs of this age and ewes are genetically similar. Raadsma et al. (1994a) reported that in deliberately infected Merino sheep of 10 to 21 months of age, the heritability for susceptibility to footrot can be as high as 0.3 when using the average of repeated measurements. The highest heritabilities were found if footrot was analyzed as a binary trait, i.e. presence or absence of footrot, or severe footrot, and using a threshold model. The genetic correlation between successive cases of footrot after re-infection ranged from 0.14 to 0.95 , with an average of 0.67 , suggesting that some different genes are involved in response to subsequent cases of footrot.

\section{Phenotypic and genetic variation in footrot resistance}

Animal health affects production economics, animal welfare, and food safety; therefore, prevention of diseases is usually preferable to curing them. In cases where there is genetic variation (the tendency of individual genotypes in a population to vary from one another) in resistance to a disease, selection may be a useful preventative measure (Bishop and MacKenzie, 2003). 
The variability of a trait describes the tendency of that trait to vary in response to environmental and genetic influences. Genetic and phenotypic variation in a population is important for biodiversity and evolution. This variability can affect an individual's response to environmental stress and lead to differential survival of organisms within a population due to natural selection of the fittest variants; without variation it is difficult for a population to adapt to environmental changes which makes it more prone to extinction (Sousa et al., 2011).

Resistance to various livestock diseases by genetic selection has been modeled by Bishop and Stear (2003) and Bishop et al. (2006). Variation in disease resistance (or susceptibility) has been found between species, between breeds, and also between individuals within breeds (Collins and Conington, 2005). Much research into genetic resistance to disease in sheep is focused on gastrointestinal parasites, footrot, and blowfly strike because they impose severe economic constraints on sheep production systems.

It is likely that successful selection of sheep with improved genetic resistance to footrot through the incorporation of footrot resistance selection into structured breeding programs would be cost-effective, reducing the current dependency on chemical solutions to control the disease, and would contribute to increased sustainability by improving animal health, welfare, and productivity (Collins and Conington, 2005). 


\section{Selection for resistance to footrot}

It is well known that, for many diseases, resistance has a genetic component (Archibald and Bishop, 2006), and selection for disease resistance has long been considered a promising way to reduce disease prevalence (Axford et al., 2000). Selection for resistance to an infectious disease has the added benefit that it may reduce the pathogen burden, especially when the population under selection is the main reservoir of pathogens. This can lead to an additional reduction in prevalence, in addition to the direct genetic effect, as a result of reduced contamination from infectious animals (Bishop and Stear, 2003). Usually a score is used as a phenotypic marker in selection for disease resistance, which includes a class of healthy animals, and one or more classes of affected animals. In the case of endemic diseases the vast majority of animals at any onetime may be classified as healthy, and this limits the opportunity for intense selection. It is expected that a successful selection program can decrease the subsequent response to selection through increased resistance and decreased pathogen burden (Nieuwhof et al., 2009).

In recent years there has been a huge increase in the research and application of disease genetics in sheep and goats which has been due to a number of factors: a growing appreciation of the role that host genetics can play in disease control, an increase in the tools available to dissect host genetic variation in disease resistance, and growing pressures on breeders to select animals that are healthier and more resistant both to infectious and metabolic diseases (Bishop and Morris, 2007). Evidence for host 
genetic variation in aspects of disease resistance has been documented for many diseases in all major domestic livestock species (Bishop, 2005), and small ruminants are notable for the large number of diseases where host genetic variation has been documented.

Assessing the genetic control of footrot and subsequently breeding for resistance is aided by the fact that footrot severity is relatively easily scored under field conditions. For example, using Australian Merino sheep, a footrot lesion scoring method was developed by Egerton and Roberts (1971) and refined by Raadsma (2000) into a system that separated clinical signs into 8 categories. Using this system, Raadsma et al. (1994a) demonstrated substantial genetic variation in resistance both to a challenge with virulent isolates of $D$. nodosus and also to a natural challenge.

A practical application of this approach has been described by Patterson and Patterson (1989) who successfully selected for enhanced footrot resistance in Merinos. Additional evidence of the feasibility of selecting sheep for footrot resistance using phenotypic observations is given by Skerman and Moorhouse (1987), who reported an evaluation of lines of New Zealand Corriedale ewes selected for enhanced footrot resistance. Therefore, breeding for enhanced footrot resistance using phenotypic assessment alone is possible and feasible, provided that footrot is present in the flock. 


\section{Phenotypic and genetic assessment for resistance to footrot}

In order to assess the genetic properties of footrot, and the degree of its severity among individual sheep, it is necessary that a reliable and repeatable method to categorize the phenotype is available. In a study by Conington et al. (2008) hoof lesion scoring was used to quantify footrot in sheep to select breeds resistant to footrot. Although selection using footrot lesion scoring has been shown to be successful (Skerman, 1985; Skerman and Moorhouse, 1987; Patterson and Patterson, 1989), if breeders maintain footrot free status, then phenotypic selection is not feasible and genetic markers may be required.

There are several potential advantages to the development and use of a molecular genetic test for footrot resistance. Scoring feet lesions and classifying them objectively and repeatably are practically difficult. In addition, with genetic markers, animals that are candidates for selection do not have to be exposed to infection to determine whether they are genetically susceptible or not. This approach can also shorten the generation interval (Collins and Conington, 2005).

A group of genes important for controlling immune response lie within the Major Histocompatibility Complex (MHC). These genes show great allelic diversity between individuals, and it is thought that some alleles are more efficient at initiating an immune response to specific pathogens than others. Data exist which suggest an association between genetic polymorphisms within the MHC Class II region and response to footrot infection (Litchfield et al., 1993; Escayg et al., 1997). Subsequently, genetic variation 
within the ovine MHC loci in the class II region, specifically at the DQA2 gene, has been used to develop genetic markers for footrot resistance (Hickfordet al., 2004). Importantly, no links were found between the variation of $D$. nodosus strain (of which there are at least 9 serogroups covering 18 subsidiary serotypes; Claxton, 1989) and resistance to footrot, so selection of resistant sheep would not be expected to be compromised by inter-strain bacteria variation. Whereas, environmental conditions, nutrition, genetics, and other factors altogether affect a sheep's resistance and tolerance to footrot. These other factors can influence resistance propensity including foot shape, foot structure, hoof color and age. Genotype by environment interaction is another effect that occurs when a set of genotypes change their relative performance in different environments (Falconer, 1981). Such genotype by environment interactions potentially have implications in the efficiency of selection to improve footrot resistance.

\section{Footrot gene-marker screening test}

Studies by Litchfield et al. (1993) and Escayg et al. (1997) have linked a group of genes called the MHC to the ability of sheep to tolerate footrot. The MHC has a central role in the immune response of vertebrates, with the function of presenting antigenic peptides to T-cells, and the class II gene region of the sheep MHC has an organization similar to that of humans (Scott et al., 1987).

Dr. Jon Hickford and a team of researchers at Lincoln University of New Zealand (2004) isolated a particular MHC gene called DQA2 with at least 26 different alleles, 
each related to different levels of susceptibility or resistance to footrot. This research has become the basis of a gene-marker test that enables sheep breeders to identify sheep that are considered less likely to get footrot.

The test includes collecting blood samples from sheep on a piece of FTA ${ }^{\mathrm{TM}}$ card. Then the DNA is extracted from the blood and analyzed to identify the particular allele combination present in that sheep. Sheep have two alleles, reflecting that they inherit one allele from each parent and thus can pass each allele on to their progeny in an approximately 50:50 ratio. Rather than revealing the exact alleles sheep possess, the test has been codified into a ' 1 ' (least likely to get footrot) to ' 5 ' (most likely to get footrot) scale. The individual alleles are placed on this scale based on the relative risk of getting footrot. Sheep with a ' 1 ' or ' 2 ' score are considered less likely to get footrot than average, and sheep with a '4' or ' 5 ' score are considered more likely to get footrot than average. Sheep with a ' 3 ' score are average (i.e. considered more likely to get footrot than those with a ' 1 ' or ' 2 ' and less likely to get footrot than those with a ' 4 ' or a ' 5 ' score).

Because sheep carry two alleles of this gene, they get two scores. Either one of these alleles could be passed on to each offspring, or so a sheep with a score of $2 / 2$ might be a better breeding sheep to have in the flock that a sheep with a score of $1 / 5$. The sheep with a 2/2 score will pass on pretty good resistance to footrot to all their lambs. Sheep with a score of $1 / 5$ will have a $50 \%$ chance of passing on the allele for footrot susceptibility to each lamb (Greer, 2007). 
CHAPTER III

COMPARISON OF SELECTED RESISTANT AND SUSCEPTIBLE

KATAHDIN SHEEP TO OVINE FOOTROT USING A GENE MARKER

SCREENING TEST

\section{Abstract}

A polymorphism at the DQA2 and DQA2-like loci located within the Major Histocompatibility Complex (MHC) was utilized to develop a gene marker screening test to identify resistant vs. susceptible genotypes in Katahdin ewes (Escayg et al., 1997). In New Zealand, a footrot gene marker test (FGMT) is commercially available as a tool to select more tolerant or resistant animals, without having to expose the animals to infection. Therefore, the objectives of this study were to identify footrot resistant genotypes in sheep by screening with the DQA2 gene marker, to identify the footrot pathogenic bacteria thermostability, and to investigate the host resistant immune response by measuring immunoglobulin $\mathrm{G}(\lg G)$ level in sera. Blood samples were collected from 600 mixed age sheep out of the marker assisted selection flock 
established at the Lincoln University Carver farm for FGMT screening and breeding (Wuliji et al., 2013a,b). Sixty-eight Katahdin and Katahdin x Dorper crossbred ewes were selected and stratified by body weight and footrot gene marker test scores (low, medium, and high resistant footrot gene marker) into control (C) and disease challenge (D) groups ( $n=34$ each). Animals selected for the disease challenge experiment were managed in specially designed isolation pasture separately from the control group. Cultures of $D$. nodosus were inoculated and administered to the inter-digital skin of the treatment group and held there with bandages for 5 days. Footrot lesions were examined (including the $C$ group, to see if there was any natural infection from the environment) and recorded weekly. Blood samples were taken weekly from the beginning of trial to week 6 and WBC count, RBC count, packed cell volume (PCV), WBC differential, and immune response measurements were recorded. Animals were weighed and given body condition scores (BCS) at the beginning and the end of trial to determine if there were any weight changes. A gelatin test was used to compare the thermostability and activity of the enzymes of two different strains of $D$. nodosus. The data were analyzed by using mixed model procedures of SAS (SAS Inst. Inc., Cary, NC) and $P<0.05$ was considered as significant. At the end of trial, all ewes in the $C$ group had a footrot score of 0 , but in the $D$ group, footrot scores were from 0 to 2 . Footrot scores at the end of trial were different $(P=0.009)$ between $C$ and $D$ groups. The average BCS at the beginning of trial was 3.2 which decreased to 2.5 at the end of trial $(P<0.0001)$. The average BCS at the end of the trial was different $(P<0.0001)$ between 
$C$ and $D$ groups. The average body weight of ewes at the beginning of trial $(54.4 \mathrm{Kg})$ decreased to $51.2 \mathrm{Kg}$ at the end of trial $(P<0.0001)$. Body weight at the end of trial was different $(P=0.0009)$ between $C$ and $D$ groups. The number of RBC per $\mathrm{mm}^{3}$ was different $(P<0.0001)$ between $C$ and $D$ groups and between the beginning and the end of trial $(P<0.0001)$. The number of neutrophils and lymphocytes was different $(P<0.05)$ at the beginning and the end of trial. The packed cell volume percentage was different $(P=0.03)$ between $C$ and $D$ groups and between the beginning and the end of trial $(P<$ 0.0001). The IgG level in sera $(\mathrm{mg} / \mathrm{ml})$ was greater in $D$ than $C$ groups $(P<0.0001)$. In the gelatin test, there was a difference $(P<0.0001)$ between the diameters of the clear zones of proteolysis around inoculated wells with $D$. nodosus at different incubation times ( 8 and $16 \mathrm{~min}$ ). No zones of proteolysis were observed around wells in control group. The gelatin test determined inoculated $D$. nodosus enzyme activity and since no virulent cases of footrot were observed during footrot pathogenic challenge, it can be an evidence of footrot resistance in the Katahdin sheep breed.

\section{Introduction}

Footrot is a chronic, painful, bacterial disease of the feet of ruminants caused by infection with the bacterium Dichelobacter nodosus in association with other bacteria, particularly Fusobacterium necrophorum (Egerton et al., 1969; Roberts and Egerton, 1969). Footrot is a common cause of lameness in both lambs and mature sheep and is considered as one of the major welfare problems and cause of economic losses in 
sheep. Footrot is highly contagious, being easily transmitted from sheep to sheep via pasture, bedding or handling pens, and can be spread by sheep that do not show clinical signs of disease (Nieuwhof and Bishop, 2005).

Environmental and host factors play an essential role in the initiation and development of the disease (Beveridge, 1934; Graham and Egerton, 1968). The severity of the disease depends on environmental, bacterial, and host factors involved in different outbreaks. In groups of small ruminants in the same environment, there will be animals which are highly susceptible, partly susceptible, or resistant (Egerton, 2002).

Recently, there has been a huge increase in the research and application of disease resistant genetics in sheep and goats due to a number of factors such as: growing appreciation of the role that host genetics can play in disease control, an increase in the tools available to dissect host genetic variation in disease resistance, and growing pressures on breeders to select animals that are healthier and more resistant both to infectious and metabolic diseases (Bishop and Morris, 2007).

Less work has been done on Quantitative Trait Loci (QTL) or genetic marker tests for footrot resistance than on phenotypic assessment of resistance; however, associations between resistance and $\mathrm{MHC}$ markers, particularly within the MHC class II region, have been published (Litchfield et al., 1993; Escayg et al., 1997). A specific association with the DQA2 gene has been used in New Zealand as a marker for footrot resistance (Hickford et al., 2004). This test is now commercially available (Hickford, 
2000) as a tool to select more tolerant or resistant animals, without having to expose the animals to infection.

The objectives of this study were to select footrot resistant genotypes in sheep by screening with the DQA2 gene marker, to identify the footrot pathogenic bacteria thermostability, and investigate host resistant immune response measuring immunoglobulin G (IgG) level in sera.

\section{Materials and Methods}

\section{Footrot gene marker test (FGMT) screening}

The alleles of the DQA2 gene were sorted on a level of susceptibility or resistance to footrot and assigned to a FGMT score between 1 and 5, with 1 and 2 indicating high resistance, and 4 and 5 signaling high susceptibility. The FGMT screening in sheep was conducted in accordance to the procedures established by Hickford (2000). Namely, fresh blood was drawn from the jugular vein of screened sheep using $1 \mathrm{ml}$ syringes fitted with a $20 \mathrm{G}$ needle. Blood was transferred to a special FTA ${ }^{\mathrm{TM}}$ card for retaining DNA. After the FTA cards were soaked with drops of whole blood they were left to dry completely at room temperature and stored for footrot resistance/susceptibility gene marker testing. Extraction of DNA was performed in a sequential manner by punching out a disk of the blood specimen on the FTA card, and placing it in PCR tubes, and subsequently washing three times with TE-1 buffer (10 mM 
Tris, 0.1 mM EDTA, pH 8.0). Then the disk was dried in a PCR tube and PCR master mix solution was added directly onto the DNA specimen disk and the extracted DNA was amplified. Extraction of DNA and gene marker test screening were processed at the Lincoln University Gene-Marker Laboratory (Christchurch, NZ). The footrot resistant alleles of the DQA2 gene were identified for each specimen and then were assigned into FGMT scores and reported for each animal. The FGMT report lists were used for animal selections, ranking from a high (1) to low (5) resistance to footrot. Although FGMT scores were provided in biallelic factions $(1,1 ; 1,5 ; 4,5 ;$ and 5,5$)$, animals were selected at the least numerical score values assuming gene expression for dominant effect (i.e., $1,5$ is $=1)$.

\section{Footrot lesion scoring, swabbing and bacteria inoculants preparation}

Natural and challenge-induced foot infections were diagnosed, footrot lesion scored, and swab sampled for bacteria culturing. Our footrot lesion scoring system was adopted from the procedure developed by Egerton and Roberts (1971), which was based on 5-point scale (0-4). Namely, a healthy foot is equal to score 0 , while mild footrot (1) is characterized by inflammation of the inter-digital space with red and often with white pasty exudates; it is likely accompanied by slight limping. The intermediate (2) footrot score is for a further extension of these symptoms, accompanied by a lifted foot when standing or limping. Virulent footrot (3) animals are obviously in distress and carrying their affected foot with constant limping. There is under-running and severe 
tissue damage in the outer hoof wall and sole. Score 4 footrot has expanded in underrunning so as to separate the hoof horn from the sensitive tissue of the claws, and the animals exhibit severe limping or walking on their knees. Footrot lesion swab samples for culture were collected from the inter-digital skin space between toes, soles or hooves using sterile cotton swabs. Two swabs were collected for each animal; one was retained in a chopped meat transport tube culture (Anaerobe Systems, CA) for bacteria culture and identification, whereas the other was obtained for bacteria DNA isolation. For the latter specimen, cotton ends of the swabs were cut off into $1.5 \mathrm{ml}$ tubes containing $1 \mathrm{ml}$ of phosphate buffered saline (PBS; $145 \mathrm{mM} \mathrm{NaCl}$, $8.7 \mathrm{mM} \mathrm{Na}_{2} \mathrm{HPO}_{4}$, $1.2 \mathrm{mM} \mathrm{NaH}_{2} \mathrm{PO}_{4}, \mathrm{pH} 8.0$ ) and $20 \mathrm{mM} \mathrm{Na}{ }_{2} \mathrm{EDTA}$ and stored at $-80^{\circ} \mathrm{C}$. Culture swab samples were transferred to an anaerobic culture chamber and subsequently streak plated onto pre-prepared deoxygenated transport medium plates and cultured at $37^{\circ} \mathrm{C}$ for $72 \mathrm{~h}$ for primary culture bacteria colony isolation in the laboratory. A number of noninfected animals were foot swab sampled for a reference isolate.

\section{Footrot bacteria inoculants preparation}

Two D. nodosus strains, ATCC 25549 (US) and ATCC 31545 (Aust) lyophilized bacteria stock were acquired from the American Type Culture Collection (ATCC, Manassas, Virginia) propagation. Each vial was flushed aseptically with $0.5 \mathrm{ml}$ liquid broth of chopped meat tube culture and the pellet was rehydrated in broth, then bacteria stock were transferred into chopped meat tube culture and incubated $24 \mathrm{~h}$ at 
$37^{\circ} \mathrm{C}$. The bacteria inoculants were cultured in an anaerobe chamber for $5 \mathrm{~d}$ prior to the challenge experiment by subculturing $D$. nodosus strains on a Brucella Blood Agar culture medium by streak plating ( $24=12$ plates/ea strain). Grown bacteria colonies were examined by smear slide preparation, Gram's staining, and microscopic examination. Bacteria colonies were wiped up with a lightly PBS moistened cotton ball while it was held with forceps and carefully pasted onto inter-digital space wounds between toes of challenged sheep, then a single layer of gauze was spread over on inter-digital wound spot.

\section{Bacteria $D$. nodosus protease thermostability determination}

The protease thermostability determination method is based on that of Palmer (1993). The substrate gel consisted of Agarose 1.0\% (w/v), Gelatin (w/v), TRIS Base 20 $\mathrm{mM}, \mathrm{CaCl}_{2} 0.5 \mathrm{mM}, \mathrm{pH} 8.8$, dissolved by boiling, and poured on a glass plate. To test the samples, 4 holes were punched into the gel and the surface of the gel was left to dry at room temperature for $2 \mathrm{~h}$. Cultures of $D$. nodosus isolates were grown in chopped meat medium for $2 \mathrm{~d}$ at $37^{\circ} \mathrm{C}$, and checked for purity by microscopic examination. Cultures normally achieved a count of $2 \times 10^{7}$ per $\mathrm{ml}$, and were then diluted $0.5 \mathrm{ml}$ into $1.5 \mathrm{ml}$ buffer (HEPES 0.1M; $\mathrm{CaCl}_{2} 0.01 \mathrm{M}, \mathrm{pH} 8.5$ ).

Aliquots $(100 \mu \mathrm{l})$ of unheated diluted samples were placed in one of the wells of the gelatin, and the remainder of the sample was placed in a water bath at $68^{\circ} \mathrm{C}$. Further $100 \mu \mathrm{l}$ aliquots were pipetted from samples after incubation times of 8 and $16 \mathrm{~min}$ and 
placed in appropriate wells. Buffer (100 $\mu \mathrm{l}$; HEPES 0.1M; $\left.\mathrm{CaCl}_{2} 0.01 \mathrm{M}, \mathrm{pH} 8.5\right)$ was

placed in wells as a control. The gel was then placed in the anaerobic chamber and incubated at $37^{\circ} \mathrm{C}$ for $18 \mathrm{~h}$. Unhydrolysed gelatin was then precipitated by immersing the gel in saturated ammonium sulphate solution at $70^{\circ} \mathrm{C}$. Photos were captured from the plates and clear zones of proteolysis around inoculated wells were measured with Scion Image software (Version 9.20, Scion Corporation).

\section{Footrot pathogenic challenge}

Katahdin and Katahdin x Dorper crossbred ewes $(n=68)$ were penned in a wet, warm, and humid environment for 7 days. Animals were stratified by body weight and FGMT scores (low, medium, and high resistant footrot gene marker) into control (C) and disease challenge (D) groups ( $n=34$ each), which were subjected to $D$. nodosus inoculation treatment. Ewes in the D group were fitted with a plastic boot filled with sheep manure/pen effluent liquid on the right front foot for 5 additional days to condition for the pathogenic challenge. All animals were examined for footrot and scald incidence, and footrot scores were recorded according to an objective scoring system. After examination, animals were challenged according to the procedures established at Lincoln University by Wuliji (2011), which was modified from the procedure of Ghimire et al. (1999) and Emery et al. (1984). The inter-digital skin was pricked with a micro lancet or blade tip to create an exposure point $(5-8 \mathrm{~mm})$ for bacterial inoculants. Preprepared bacterial inoculant media on adhesive tape was attached onto the inter-digital 
skin/toe wound area of right foot of challenge animals and bound to the crown of the hoof, and held with bandages for 5 days. Plastic boots were placed back on the feet of challenge animals after inoculation. Animal behavior was observed daily and any symptomatic development during the challenge period was recorded. Footrot and lesion scores were examined (including controls) and recorded. At the end of the challenge experiment, all challenge animals were examined and treated with long-acting antibiotic injections and sprays for 2 weeks or until pathogen clearance. Animals were pen fed together for 2 weeks pretrial, 6 weeks for the challenge and 4 weeks for postchallenge observation. Care was taken to prevent cross-contamination between the groups during feeding and handling. Animals were examined weekly and scored for severity of footrot lesions. Any animal with score 2 or more in one or more feet was defined as 'affected'.

Footrot lesions were examined (including the $C$ group, to see if there was any natural infection from the environment) and recorded weekly. Blood samples were taken weekly from the beginning of trial to week 6 and WBC count, RBC count, packed cell volume (PCV), and WBC differential were done to determine the percentage of neutrophils, lymphocyte, eosinophils, monocytes and basophils. The quantitative measurement of immune response by Immunoglobulin $\mathrm{G}(\mathrm{IgG} ; \mathrm{mg} / \mathrm{ml})$ to footrot infection was measured by using an ELISA kit (GenWay, Biotech, Inc.). Animals were weighed and assigned body condition scores (BCS) at the beginning and the end of trial. 
At the end of the challenge phase, all ewes were examined and those with no footrot symptoms and lesions were considered resistant. Bacteria culture swabs were taken and ewes were treated with antibiotic spray and Hoof Phast powder (Mid-States Wool Growers) as a foot bath twice a week for 3 weeks. After 3 weeks of treatment, reinspection of ewes, scores footrot lesions, and bacteria swabs for bacteria isolation and identification occurred. The ewes in challenge group were culled at the end of the trial.

\section{White blood cell count}

A sample of whole blood was drawn exactly to the 0.5 mark in a white blood cell diluting pipette and then immediately a $1 \%$ hydrochloric acid solution (which lyses nonnucleated red blood cells) was drawn to the "11" mark and mixed for 3-5 minutes to ensure even distribution of cells. The unmixed and relatively cell-free fluid from the capillary portion of the pipette was expelled (usually 4 drops). A Neubauer hemocytometer was used as the counting chamber. The cells were allowed to settle for about 3 minutes and the number of white cells in the four $1 \mathrm{~mm}^{2}$ corner areas was counted in both chambers. The formula was as follows:

WBC per $\mathrm{mm}^{3}=$ Average number of WBC counted in both chambers $\mathrm{x}$ dilution (20) Volume (0.4) 


\section{$\underline{\text { Red blood cell count }}$}

Using a red blood cell diluting pipette, a sample of whole blood was drawn exactly to the 0.5 mark and then Ringer's Solution $(860 \mathrm{mg} \mathrm{NaCl}, 30 \mathrm{mg} \mathrm{KCl}, 35 \mathrm{mg} \mathrm{CaCl} 2$ dissolved in $100 \mathrm{ml}$ distilled water) was drawn to the "101" mark and mixed well. Half of the pipette was emptied into a waste container and the Neubauer hemocytometer was used as the counting chamber. The cells were left to settle for $1 \mathrm{~min}$ and the number of red blood cells was counted in each of five fields (each with 16 smallest squares). The number of RBC per $\mathrm{mm}^{3}$ was calculated by adding the cells in the 5 groups and multiplying by 10,000 .

\section{Packed cell volume (PCV) measurement}

For PCV, a microhematocrit tube was dipped into blood and blood rose to the desired two-thirds to three-quarters level. After cleaning the outside of the tube of excess blood, the bottom of the tube was sealed with sealant. Tubes were placed in a microhematocrit centrifuge and spun for $1 \mathrm{~min}$ at 10,000 RPM. Blood was separated into layers (plasma, buffy coat including leukocytes and platelets, and red blood cell). The centrifuged hematocrit tube was placed on a reader with the top of the clay sealant at the $0 \%$ mark and the top of the plasma layer at $100 \%$. The percentage of RBC which is read at the top of the RBC layer represents the PCV. 


\section{$\underline{\text { WBC differential test }}$}

Blood smears were spread on glass slides to count the number of neutrophils, basophils, lymphocytes, eosinophils, monocytes (differential cell count) by microscopic examination after Wright staining (95 $\pm 1 \%$; mean \pm SEM). Slides were left at room temperature for $2 \mathrm{~min}$ to dry and then were fixed for at least $30 \mathrm{~s}$ in absolute methanol. Methanol was removed by tilting the slides and the filtered staining solution $(0.3 \mathrm{~g}$ of Wright stain powder dissolved in $100 \mathrm{ml}$ absolute methanol) was applied for $2 \mathrm{~min}$ on a horizontally positioned slide. Buffer solution (KH2PO4, anhydrous 6.63 g; Na2HPO4, anhydrous $2.56 \mathrm{~g}$; distilled water up to $1,000 \mathrm{ml}$ ) was added and gently mixed with the stain and was let stand for 3 min. Slides were rinsed with (distilled) water for $30 \mathrm{s.} \mathrm{A}$ low-power lens (10 $\mathrm{x}$ objectives) on the light microscope was used to check the approximate differential cell distribution. Then, the 40x objective high-power lens was used to perform a 100 cell differential count. One hundred white blood cells were counted and the percentage of neutrophils, basophils, lymphocytes, eosinophils, and monocytes were determined.

\section{Immune response assay}

Blood collected by vacutainer from jugular veins of sheep in both control $(n=34)$ and treatment $(n=34)$ groups during footrot pathogenic challenge was centrifuged at 2,000 RPM for 5 min to separate the serum and the quantitative measurement of 
immune response by Immunoglobulin $\mathrm{G}(\mathrm{IgG} ; \mathrm{mg} / \mathrm{ml})$ to footrot infection was measured by using an ELISA kit (GenWay, Biotech, Inc. San Diego, CA).

\section{$\underline{\text { Statistical analysis }}$}

Data were analyzed by using mixed model procedures of SAS (SAS Inst. Inc., Cary, NC) and $P<0.05$ was considered as significant.

Body condition score, body weight, and footrot scores at the end of the trial, PCV, WBC, RBC, IgG were fitted as dependent variables. Body condition score and body weight at the beginning of trial were fitted as covariates. Gene marker group, challenge group (control and treatment) and, breed were fitted as independent variables of interest. In gelatin test, diameter of the clear zones of proteolysis around inoculated wells was fitted as dependent variable and incubation time and bacteria strains were fitted as independent variables of interest. Differences in least-squares means were tested using Tukey's Honest Significant Difference (HSD)

\section{$\underline{\text { Results }}$}

Bacillus licheniformis, Bacillus safensis, Enterococcus faecalis, E.coli, Staphylococcus epidermidis, and Staphylococus aureus were isolated from culture swabs of inter-digital space at the end of trial. Footrot and lesion scores of ewes in both $\mathrm{C}$ and D groups were 0 (normal hooves) at the beginning of footrot pathogenic trial. At the end 
of trial all the ewes in $\mathrm{C}$ group had a footrot score 0 but in $\mathrm{D}$ group the footrot scores ranged from $0-2$. There was no difference $(P=0.88)$ between footrot scores of different footrot gene marker groups at the end of trial. Footrot score at the end of trial was different $(P=0.01)$ between $C$ and $D$ groups. Sheep breed did not affect $(P=0.38)$ the footrot score at the end of trial. Challenge group by marker interaction $(P=0.87)$, breed by marker interaction $(P=0.11)$, challenge group by breed interaction $(P=0.38)$, and challenge group by breed by marker interaction $(P=0.11)$ did not affect the footrot score at the end of trial. Hoof color did not affect $(P=0.12)$ footrot score at the end of trial (Table 1).

The average BCS of ewes at the beginning of the trial was 3.2, which decreased to 2.5 at the end of trial $(P<0.0001)$. The average BCS at the end of trial was greater in $C$ group than that of $D$ group $(P<0.0001 ;$ Figure 1$)$. Body condition score was not different $(P=0.35)$ among different marker groups. Sheep breed did not affect $(P=0.46)$ BCS at the end of trial. Challenge group by marker interaction $(P=0.77)$, breed by marker interaction $(P=0.38)$, challenge group by breed interaction $(P=0.72)$, and challenge group by breed by marker interaction $(P=0.62)$ did not affect the BCS at the end of trial.

The average body weight of ewes at the beginning of trial ( $54.4 \mathrm{Kg})$ decreased to $51.2 \mathrm{Kg}$ at the end of trial $(P<0.0001)$. Body weight at the end of trial was greater in $\mathrm{C}$ group than that of $\mathrm{D}$ group $(P=0.0009$; Figure 2$)$. Body weight was not different $(P=$ $0.26)$ among different marker groups. Sheep breed did not affect $(P=0.58)$ body weight 
at the end of trial. Challenge group by marker interaction $(P=0.79)$, breed by marker interaction $(P=0.71)$, challenge group by breed interaction $(P=0.09)$, and challenge group by breed by marker interaction $(P=0.11)$ did not affect the body weight at the end of trial.

The number of RBC and WBC per $\mathrm{mm}^{3}$ was calculated in both $C$ and $D$ groups weekly. The number of RBC per $\mathrm{mm}^{3}$ was not different $(P=0.31)$ among marker groups. The number of RBC per $\mathrm{mm}^{3}$ was greater in $\mathrm{D}$ than $\mathrm{C}$ group $(P<0.0001)$. The number of WBC per $\mathrm{mm}^{3}$ was not different $(P=0.76)$ among different marker groups. The number of WBC per $\mathrm{mm}^{3}$ was not different $(P=0.96)$ between $C$ and $D$ groups and from the beginning to the end of trial $(P=0.77$; Table 2$)$. The number of neutrophils increased from the beginning to the end of trial $(P=0.04)$ but the number of lymphocytes decreased from the beginning to the end of trial $(P=0.03)$. The number of eosinophils $(P$ $=0.62)$, monocytes $(P=0.5)$, and basophils $(P=0.76)$ was not different from the beginning to the end of trial (Table 3). The PCV percentage was not different $(P=0.17)$ among different marker groups, but it was greater in $D$ than $C$ group $(P=0.03)$ and it was greater in the beginning than the end of trial $(P<0.0001 ;$ Table 2$)$.

The IgG level in sera $(\mathrm{mg} / \mathrm{ml})$ was not different $(P=0.45)$ among different marker groups, and between the beginning and the end of trial $(P>0.05)$. The IgG level in sera $(\mathrm{mg} / \mathrm{ml})$ was greater in $\mathrm{D}$ than $\mathrm{C}$ group $(P<0.0001$; Figure 3$)$.

The diameters of the clear zones of proteolysis around inoculated wells in the gelatin test determined the thermostability and activity of $D$. nodosus enzymes (Figure 
4). There was no difference $(P=0.99)$ between the diameters of the clear zones of proteolysis around inoculated wells of two different bacteria strains. The diameters of the clear zones of proteolysis around inoculated wells decreased $(P<0.0001)$ after 8 and $16 \mathrm{~min}$ of incubation (Figures 5 and 6). No clear zone of proteolysis was observed around the wells in control samples (Figure 4).

\section{Discussion}

Footrot scores of animals in the control group were zero during the trial, which suggested that there was no natural infection from the environment. Ten out of 34 animals in treatment group had footrot score 1, which represents mild inter-digital dermatitis or scald with some loss of hair and light to moderate inflammation confined to inter-digital skin. Two out of 34 had footrot score 2 in which there is more extensive inter-digital dermatitis and necrotizing inflammation of inter-digital skin and 22 out of 34 had normal hooves with footrot score 0 . Footrot scores 3 and 4 were not observed in animals, which could have been due to low potency of the inoculated bacteria. Footrot gene marker score, sheep breed, and hoof color did not affect footrot score at the end of the trial.

It is notable that swab samples were collected from inter-digital space of the feet of ewes at the end of trial and $D$. nodosus and $F$. necrophorum were not isolated from those culture swabs. However, the average daily temperature at the time of trial was below $10^{\circ} \mathrm{C}$, but the fitted plastic boots were used to simulate the condition for footrot 
pathogenic challenge. The clear zones of proteolysis around inoculated wells in the gelatin test proved the protease activity of $D$. nodosus. After 8 and 16 min of incubation at $68^{\circ} \mathrm{C}$, the diameter of this zone decreased which showed the thermostability of the bacteria enzymes and decrease in enzyme activity. Both F. necrophorum and $D$. nodosus are essential for the invasion of the epidermal matrix of the hoof and neither bacterial species alone will cause a footrot lesion. F. necrophorum colonizes the stratum corneum first, facilitating infection with $D$. nodosus. The established $D$. nodosus infection allows $F$. necrophorum to penetrate more deeply into the tissue, causing further inflammation and destruction of epidermal tissue (Egerton et al., 1969; Roberts and Egerton, 1969). In this study micro lancets were used to create an exposure point for bacteria inoculants to create footrot.

Katahdin sheep are hair sheep considered to be resistant to internal parasites and footrot. In this study none of the animals showed any signs of virulent footrot. Footrot gene marker and sheep breed did not significantly affect the footrot score at the end of trial.

Body Condition Scores are a practical management tool to be used in conjunction with nutritional and other management strategies to optimize production of the flock. Body condition scores are subjective in nature and utilize a five point scoring system (1-5) to classify sheep according to body fatness. The average body weight and BCS of the ewes decreased during trial and ewes in treatment group lost 
more weight and BCS score than control group. Weight lost might be due to stress (fitting plastic boots, bacteria inoculation) induced during the trial.

The number of neutrophils increased $(P<0.05)$ at the end of trial. Bacterial infection, acute stress, or trauma can increases the number of white blood cells. High white blood cell counts may be due to inflammation or an immune response (The Merck Veterinary Manual, 2013).

When a B lymphocyte encounters an antigen, it is stimulated to mature into a plasma cell or a memory B cell. Plasma cells release antibodies also called immunoglobulin (Ig). IgG is the most prevalent class of antibody isotype found in blood and extracellular fluid which controls infection of body tissues (The Merck Veterinary Manual, 2013). In this study the IgG level in sera of both treatment and control groups was in the normal range $(7.6-40 \mathrm{mg} / \mathrm{ml})$, however; it was greater in treatment than control group $(P<0.0001)$. Since no active infection happened in animals, the IgG level in sera remained in the normal range in both control and treatment groups and the higher level of IgG in treatment group might be due to bacteria inoculation or higher stress perception (Maes et al., 1997).

Neutrophils crosstalk with the adaptive immune system by binding to IgG on opsonized microbes (Pasquier et al., 2005; Tsuboi et al., 2008). Notably, neutrophils also produce a cytokine BAFF (B cell activating factor) which promotes the survival and differentiation of B cells and immunoglobulin-secreting plasma cells (Scapini, 2003; 
Schneider et al., 1999), triggers IgM production and class switching from IgM to IgG or IgA (Litinskiy, 2002; He et al., 2010).

The footrot gene marker test is a helpful method to distinguish and select animals with higher resistance to footrot without inducing bacteria and causing stress. However, in this study gene marker group did not affect BCS, body weight, and footrot scores, PCV, the number of RBC and WBC, WBC differential, and IgG level in sera at the end of trial. Gelatin test determined the bacteria enzyme activity, however, in the current study no virulent footrot happened, and only two animals were affected with footrot score of 2 . Therefore; the absence of footrot scores of 3 and 4 can be due to low potency of the inoculated bacteria in the trial or the fact that Katahdin is considered to be resistant to footrot. 
Figure 1: Comparison of average body condition score at the end of trial between control (C) and treatment (D) groups $(P<0.0001)$.

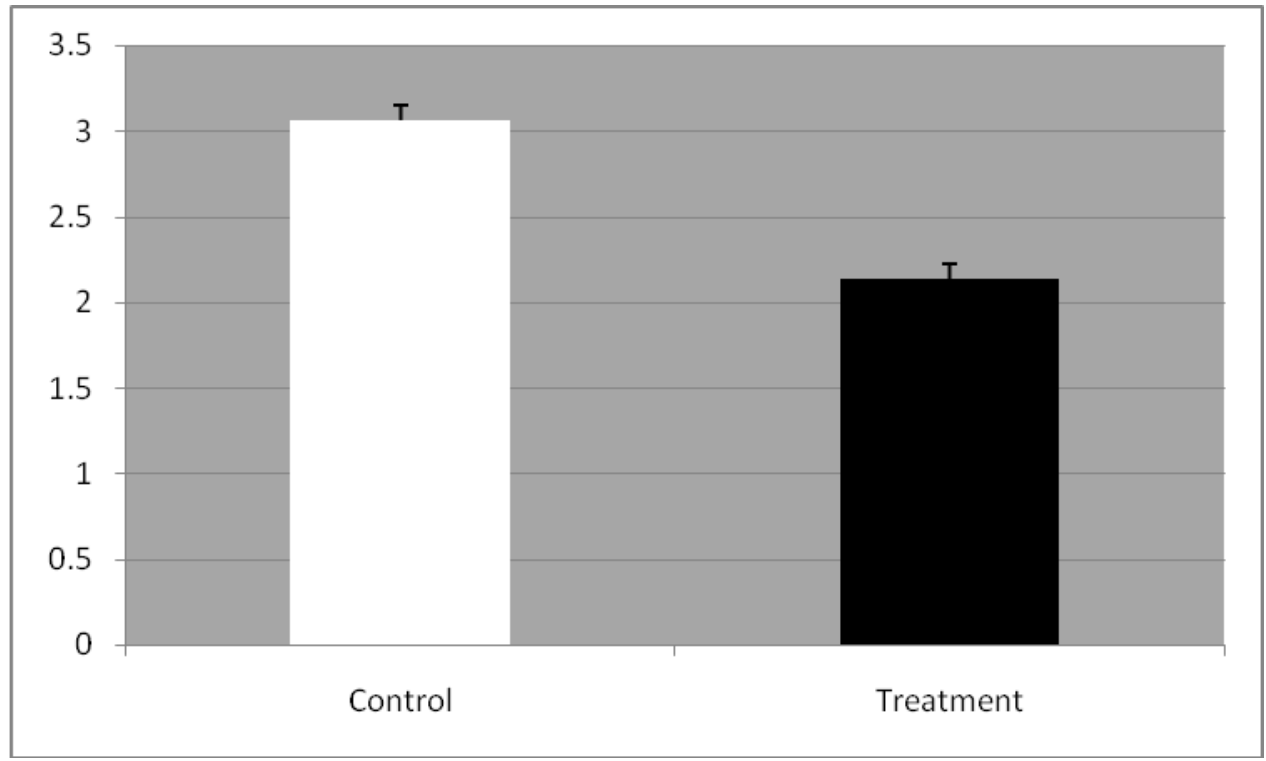


Figure 2: Comparison of average body weight at the end of trial between control (C) and treatment (D) groups $(P=0.0009)$.

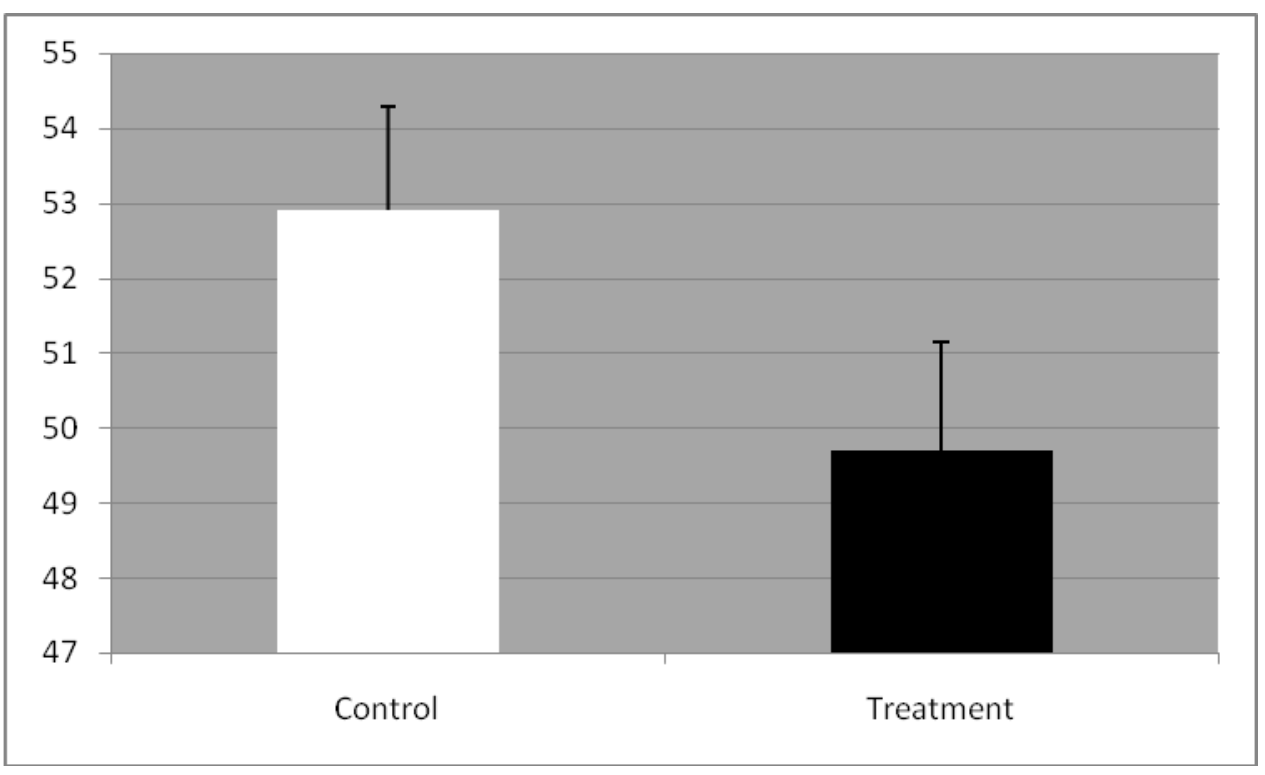


Figure 3: Comparison of IgG level in sera between control (C) and treatment (D) groups $(P<0.0001)$.

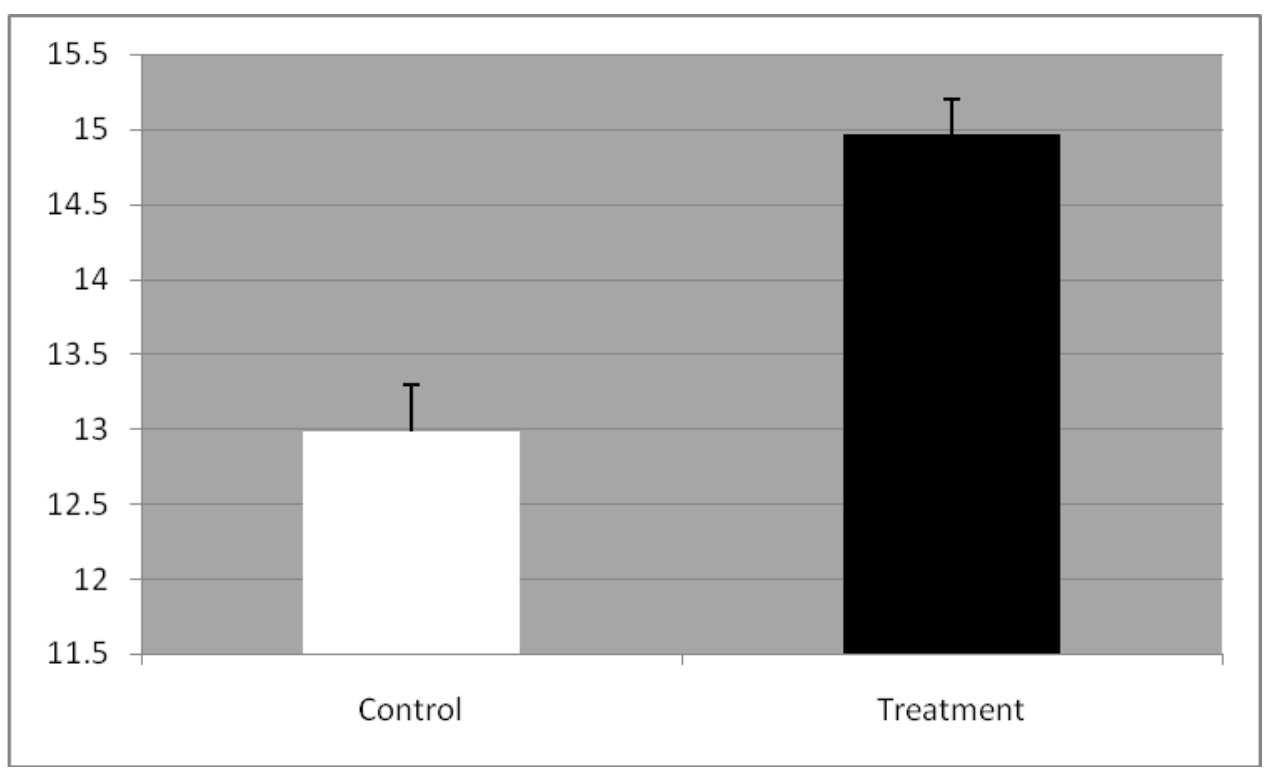


Figure 4: Clear zones of proteolysis around inoculated wells with $D$. nodosus in the gelatin test before incubation (two wells on the bottom of the petri dish). No clear zones were observed around wells in control group (two wells on top of the petri dish).

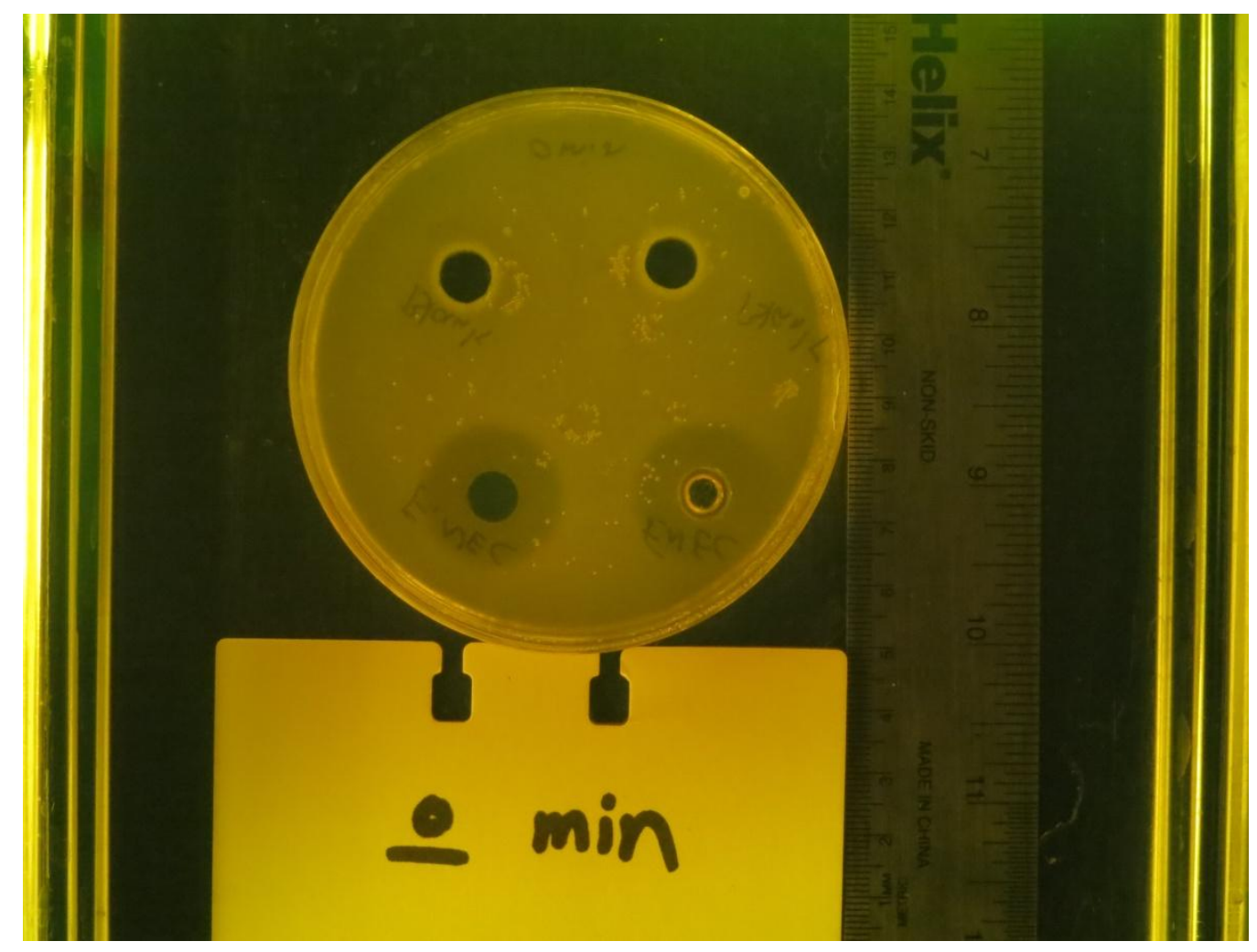


Figure 5: Clear zones of proteolysis around inoculated wells with $D$. nodosus in the gelatin test 8 min incubation $(P<0.0001)$.

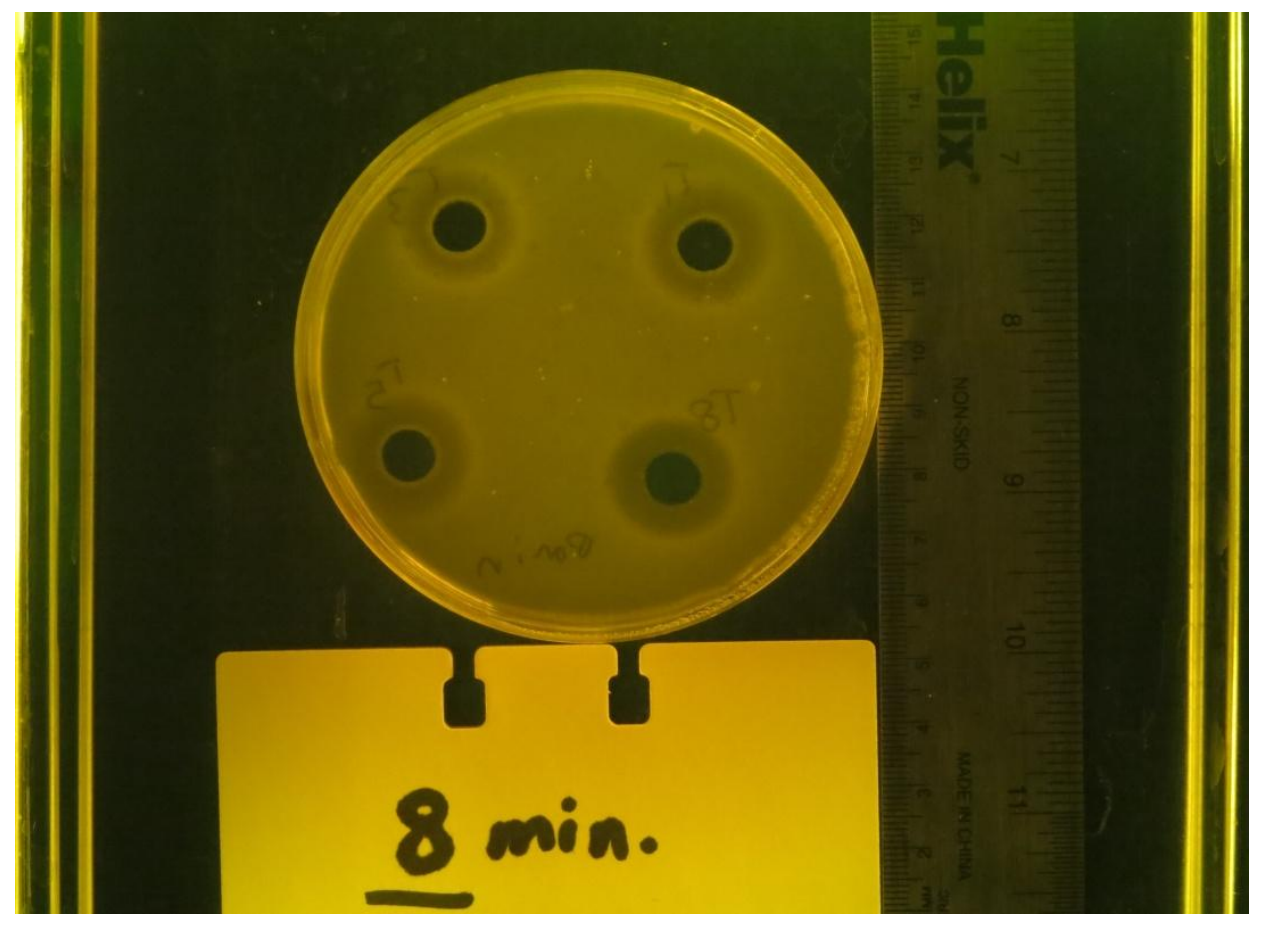


Figure 6: Clear zones of proteolysis around inoculated wells with $D$. nodosus in the gelatin test $16 \mathrm{~min}$ incubation $(P<0.0001)$.

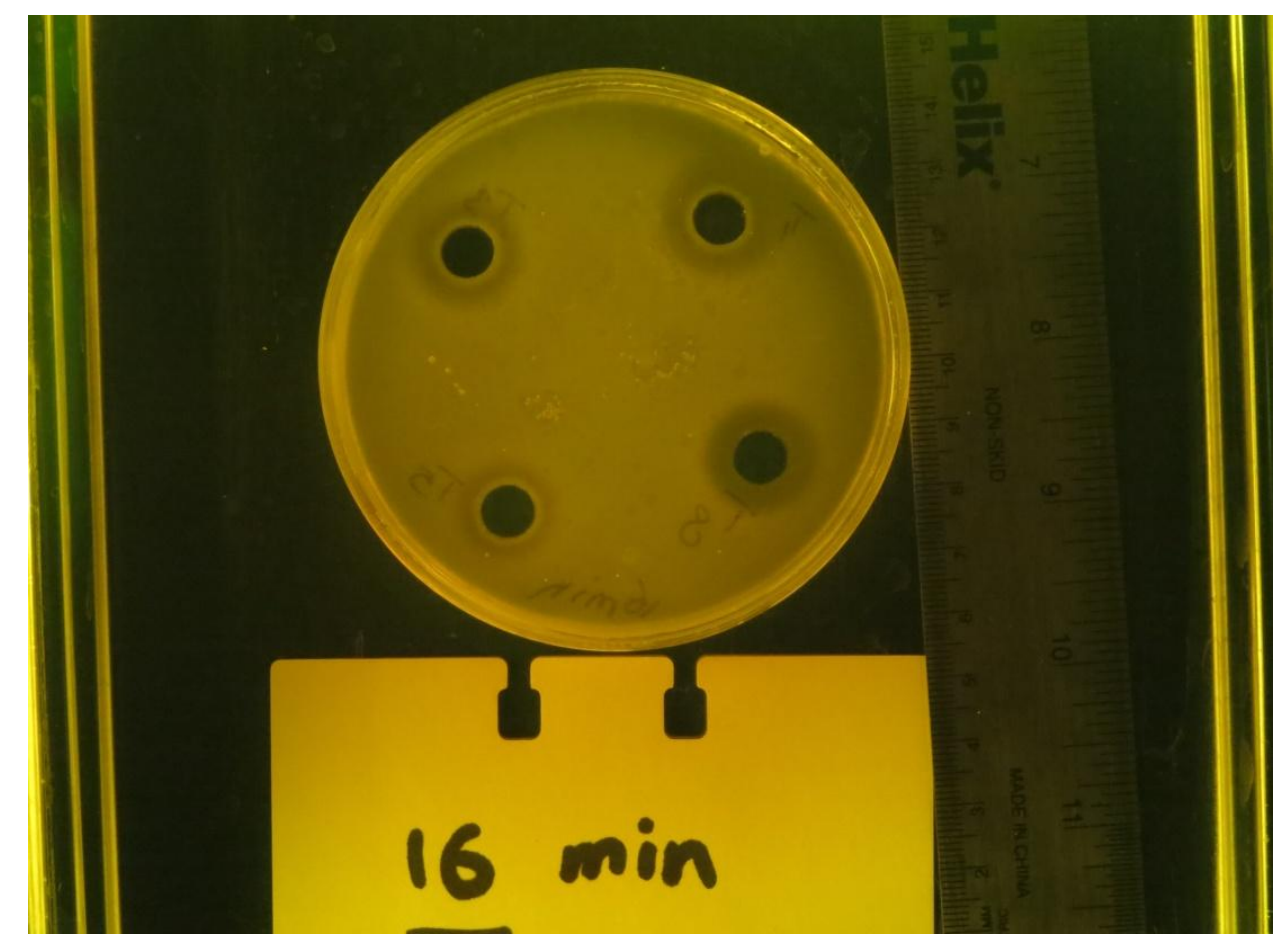


Table 1: Footrot scores by hoof color, gene marker (low, medium and high resistance) and breed in treatment (D) group.

\begin{tabular}{|c|c|c|c|c|c|c|c|c|c|}
\hline & \multirow{2}{*}{$\begin{array}{c}\text { Footrot } \\
\text { Score }\end{array}$} & \multicolumn{3}{|c|}{ Hoof color } & \multicolumn{3}{|c|}{ Gene marker } & \multicolumn{2}{|c|}{ Breed } \\
\hline & & White & Black & Colored & LR & MR & $\mathrm{HR}$ & Katahdin & $\begin{array}{c}\text { Katahdin } \mathrm{x} \\
\text { Dorper }\end{array}$ \\
\hline \multirow{3}{*}{ 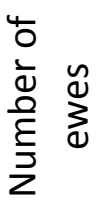 } & 0 & 5 & 4 & 13 & 7 & 9 & 6 & 14 & 8 \\
\hline & 1 & 1 & 5 & 4 & 5 & 3 & 2 & 8 & 2 \\
\hline & 2 & 0 & 1 & 1 & 0 & 1 & 1 & 1 & 1 \\
\hline
\end{tabular}


Table 2: Average RBC count, WBC count, and PCV in control (C) and treatment (D) groups at the beginning ( $C B$ and $D B$ ) and the end of trial (CE and $D E)$.

\begin{tabular}{|c|c|c|c|}
\hline Group & RBC/ $\mu \mathrm{l}$ & WBC/ $\mu \mathrm{l}$ & \%PCV \\
\hline CB & $10.57 \times 10^{6} \pm 1.29$ & $5.87 \times 10^{3} \pm 6.64$ & $34.76 \pm 5.91$ \\
\hline CE & $5.28 \times 10^{6} \pm 1.74$ & $5.85 \times 10^{3} \pm 5.12$ & $29.15 \pm 2.07$ \\
\hline DB & $10.65 \times 10^{6} \pm 1.3$ & $5.88 \times 10^{3} \pm 5.97$ & $31.25 \pm 2.04$ \\
\hline DE & $10.82 \times 10^{6} \pm 1.19$ & $5.89 \times 103 \pm 6.01$ & $31.02 \pm 2.64$ \\
\hline
\end{tabular}


Table 3: WBC differential count in $C$ and $D$ groups at the beginning ( $C B$ and $D B$ ) and the end of trial (CE and DE).

\begin{tabular}{|c|c|c|c|c|c|}
\hline Group & Neutrophil & Lymphocyte & Eosinophil & Monocyte & Basophil \\
\hline CB & $51.16 \pm 5.38$ & $43.66 \pm 4.84$ & $2.93 \pm 1.99$ & $1.2 \pm 0.55$ & $1.03 \pm 0.49$ \\
\hline CE & $53.63 \pm 4.35$ & $40.8 \pm 4.21$ & $3.36 \pm 1.58$ & $1.13 \pm 0.43$ & $1.06 \pm 0.36$ \\
\hline DB & $51.05 \pm 7.82$ & $43.35 \pm 7.78$ & $3.58 \pm 1.76$ & $0.94 \pm 0.77$ & $1.05 \pm 0.54$ \\
\hline DE & $53.82 \pm 7.17$ & $41.11 \pm 7.7$ & $2.97 \pm 1.46$ & $1.11 \pm 0.4$ & $0.97 \pm 0.45$ \\
\hline
\end{tabular}


CHAPTER IV

COMPARISON OF WHITE BLOOD CELL PHAGOCYTIC EFFICIENCY

IN FOOTROT RESISTANT VS. SUSCEPTIBLE GENOTYPES OF

\author{
KATAHDIN SHEEP
}

\title{
Abstract
}

The production and deployment of phagocytes are central functions of the hematopoietic system. Neutrophils are the most abundant type of white blood cells in mammals and are an essential part of the innate immune system. The objective of this study was to compare the phagocytic efficiency of neutrophils in footrot resistant vs. susceptible genotypes of Katahdin sheep. Thirty-seven Katahdin ewes and rams were selected from high resistance (HR) and low resistant (LR) footrot gene markers. Blood samples were collected in vacutainer tubes $(2 \times 10 \mathrm{ml})$ containing EDTA weekly for 8 weeks. Blood smears were made on glass slides to determine the percentage of neutrophils in whole blood. Neutrophils were isolated using a Percoll gradient technique 
and stained with $0.8 \mathrm{mM}$ Trypan Blue to determine the percentage of viable cells. Subsequently, $1 \mathrm{ml}$ of freshly isolated neutrophils was inoculated with $1 \mathrm{ml}$ of Lactobacillus casei $\left(2 \times 10^{7} / \mathrm{ml}\right)$ in PBS and incubated with rotation at $37^{\circ} \mathrm{C}$ for three time periods. Control samples were incubated in PBS with neutrophils alone to account for bacterial growth during the assay. At specific intervals of 20,40 , and 60 min the number of surviving bacteria in the supernatant (extracellular) was determined by culture plate colony counting to estimate the phagocytic efficiency of the neutrophils. The data were analyzed by using mixed model procedures of SAS (repeated measures) and $P<0.05$ was considered as significant. The average viability of extracted neutrophils was $95 \%$ in each individual specimen at inoculation. The percentage of neutrophils in whole blood was not different $(P=0.48)$ between the two genotypes and between rams and ewes $(P$ $=0.36)$. The effect of gene marker and sex interaction on the percentage of neutrophils in whole blood was not different $(P=0.38)$. There were significant differences among the numbers of bacterial colonies after addition of neutrophil and incubation periods between the two genotypes $(P=0.0006)$ or between rams and ewes $(P=0.02)$. The number of bacterial colonies decreased after 20,40 , and 60 min of incubation $(P<$ 0.001). The interaction of sex and gene marker groups affected $(P=0.0005)$ the numbers of bacterial colonies after addition of neutrophils. The interaction of incubation time and gene marker groups $(P=0.25)$ and the interaction of sex and incubation time $(P=0.49)$ did not affect the numbers of bacterial colonies after addition of neutrophils. The interaction of sex, incubation time and gene marker groups did not 
affect the numbers of bacterial colonies after addition of neutrophils $(P=0.93)$. The number of bacterial colonies in bacteria stock without neutrophil addition increased $(P<$ 0.001 ) after 20,40 , and 60 min of incubation. No bacterial colony growth was observed in control samples. The neutrophils in high resistant genotypes of Katahdin sheep have significantly more efficient phagocytic activity vs. low resistant genotypes.

\section{Introduction}

Innate immunity is the first-line host defense against pathogenic microbes. Its major cellular components are phagocytes such as dendritic cells (DC), macrophages, and polymorphonuclear cells (PMN) including neutrophils, eosinophils, and basophils (Wu et al., 2013).The process of engulfing a solid particle by a phagocyte to form an internal phagosome is called phagocytosis, which is a specific form of endocytosis involving the vesicular internalization of solids such as bacteria. This process is a major mechanism used to remove pathogens, cell debris, bacteria, dead tissue cells, and small mineral particles (Parham, 2009).

Phagocytes are divided into "professional" and "non-professional" depending on how effective they are at phagocytosis (Ernst and Stendahl, 2006). The professional phagocytes include neutrophils, monocytes, macrophages, dendritic cells, and mast cells (Ernst and Stendahl, 2006, Robinson and Babcock, 1998) which have receptors on their surfaces to detect harmful objects, such as bacteria, that are not normally found in the 
body (Ernst and Stendahl, 2006). The role of phagocytes include fighting infections as well as maintaining healthy tissues by removing dead and dying cells that have reached the end of their lifespan (Thompson, 1995). During the acute phase of inflammation, phagocytes are attracted by chemical signals such as Interleukin-8 (IL-8), C5a, NFormylmethionyl-leucylphenylalanine (fMLP) and Leukotriene B4 which come from bacteria or from other phagocytes already present to places where the pathogen has invaded the body (Cohen and Burns, 2002). When phagocytes come into contact with bacteria, the receptors on the phagocyte's surface will bind to them. This binding leads to engulfing of the bacteria by the phagocyte (Janeway et al., 2001). The bacterium is trapped in a compartment called a phagosome and within one minute the phagosome merges with either a lysosome or a granule to form a phagolysosome. The bacterium is then subjected to an overwhelming array of killing mechanisms (Delves et al., 2006) and is dead a few minutes later (Hampton et al., 1994). The objective of this study was to compare the phagocytic efficiency of neutrophils in footrot resistant vs. susceptible genotypes of Katahdin sheep.

\section{Materials and Methods}

Thirty-seven Katahdin ewes and rams were selected on the basis of high resistance (HR) and low resistant (LR) footrot gene markers. Ten $\mathrm{ml}$ of sheep blood were collected in EDTA tubes via jugular vein venipuncture and transported on ice to the lab in small animal research facility at Lincoln University. Blood smears were spread on glass 
slides to count the number of neutrophils (differential cell count) by microscopic examination after Wright staining (95 $\pm 1 \%$; mean \pm SEM; Hall et al., 2011).

Sheep blood was transferred into $50 \mathrm{ml}$ tubes, and centrifuged at $1,000 \times \mathrm{g}$ for 20 min at $4^{\circ} \mathrm{C}$ to separate plasma and buffy coats from the red cell pack. Plasma, buffy coat, and one-third of the red cell pack from each tube were aspirated aseptically and discarded. The remaining red cell packs containing neutrophils were mixed with $34 \mathrm{ml}$ of ice-cold PBS and layered onto $10 \mathrm{ml}$ of $1.084 \mathrm{~g} / \mathrm{ml}$ Percoll then centrifuged at $400 \times \mathrm{g}$ for $40 \mathrm{~min}$ at $22^{\circ} \mathrm{C}$. After centrifugation, red blood cells (RBC) and neutrophils were pelleted at the bottom of the tube and the mononuclear cell band remained at the medium interface. Supernatant, the mononuclear cell layer, and Percoll were aspirated and discarded. Red blood cells were lysed using $24 \mathrm{ml}$ ice-cold hypotonic lysing solution (10.56 mM Na2HPO4, 2.67 mM NaH2PO4, pH 7.3) for 90 s. Isotonicity was restored by adding $12 \mathrm{ml}$ ice-cold hypertonic restoring solution (10.56 mM Na2HPO4, $2.67 \mathrm{mM}$ $\mathrm{NaH} 2 \mathrm{PO} 4,0.43 \mathrm{M} \mathrm{NaCl}, \mathrm{pH}$ 7.3). Remaining leukocytes were pelleted by centrifugation at $800 \times \mathrm{g}$ for $5 \mathrm{~min}$ at $4^{\circ} \mathrm{C}$ (Hall et al., 2011). Trypan blue (0.8 $\mathrm{mM}$ in PBS) was used to assure that the isolated neutrophils were alive.

The bacteria stock (Lactobacillus casei) stored at $-80^{\circ} \mathrm{C}$ in a PBS solution was revived by transferring to a nutrient broth-based culture tube and was incubated at $37^{\circ} \mathrm{C}$ in a cell incubator overnight. The bacteria were separated by centrifuging the broth at 1,000 x g for 5 min and washing twice in PBS (Hampton et al., 1994). 
In order to count the bacteria, dilutions were made as follows: the bottom of three petri plates and four tubes of saline $10^{-2}, 10^{-4}, 10^{-6}$ and $10^{-8}$ were labeled. The initial dilution was made by transferring $0.1 \mathrm{ml}$ of inoculated broth medium to a $9.9 \mathrm{ml}$ sterile saline blank or PBS solution. This was a $1 / 100$ or $10^{-2}$ dilution. The $10^{-2}$ dilution was then shaken by grasping the tube between the palms of both hands and rotating quickly to create a vortex. Immediately after the $10^{-2}$ dilution was shaken, $0.1 \mathrm{ml}$ was aseptically transferred to a second $9.9 \mathrm{ml}$ saline blank or PBS solution. This second blank represented a $10^{-4}$ dilution of the original sample. Then the $10^{-4}$ dilution was vigorously shaken and $0.1 \mathrm{ml}$ was transferred to the third $9.9 \mathrm{ml}$ blank. This third dilution represented a $10^{-6}$ dilution of the original sample. The process was repeated once more to produce a $10^{-8}$ dilution. The $10^{-4}$ dilution was shaken again and $0.1 \mathrm{ml}$ was transferred aseptically to a sheep blood agar plate and spread with a disposable loop. Procedures were followed the same for the $10^{-6}$ and the $10^{-8}$ dilutions. Plates were inverted and incubated at $37^{\circ} \mathrm{C}$ for $24 \mathrm{~h}$. At the end of the incubation period, colonies were counted and the number of bacteria (CFU) per milliliter was calculated by dividing the number of colonies to the dilution factor multiplied by the amount of specimen added to agar plates as shown below (Todar, 2008):

Number of bacteria/ml = Number of colonies (CFU) / dilution X amount plated.

Bacteria were mixed with neutrophils in PBS and incubated with rotation at $37^{\circ} \mathrm{C}$ for $1 \mathrm{~h}$. Control samples were incubated in PBS with neutrophils alone to account for bacterial growth during the assay. At specific intervals of 20,40 , and $60 \mathrm{~min}$, samples 
were removed and the extracellular bacteria which were not phagocytosed were separated from the neutrophils by centrifugation at $100 \times \mathrm{g}$ for $5 \mathrm{~min}$. The number of bacteria in the stock (without neutrophils) was counted to account for changes in the absence of phagocytosis. The number of viable bacteria in the supernatant (extracellular) was determined by colony counting as described previously (Todar, 2008), and the rate of phagocytosis was calculated using the number of bacterial colonies before and after mixing neutrophils and bacteria (Hampton et al., 1994). The data were analyzed by using mixed model procedures of SAS (repeated measures) and $P$ $<0.05$ was considered as significant. The number of bacterial colonies and the number of neutrophils were fitted as dependent variable and gene marker group, sex and incubation time were fitted as independent variables of interest. Differences in leastsquares means were tested using HSD.

\section{$\underline{\text { Results }}$}

The average viability of extracted neutrophils was $95 \%$ in each individual specimen at inoculation. The average percentage of neutrophils in whole blood was $53 \%$ in all animals. The percentage of neutrophils in whole blood was not different between the two genotypes $(P=0.48)$ and between rams and ewes $(P=0.36)$. Gene marker by sex interaction had no effect $(P=0.38)$ on the percentage of neutrophils in whole blood. The numbers of bacterial colonies after addition of neutrophils and incubation periods in the low resistant gene marker group was greater $(P=0.0006)$ than that of the high 
resistant gene marker group (Figure 7). Number of bacterial colonies after addition of neutrophils and incubation periods was greater in ewes than rams $(P=0.02$; Figure 8$)$. The interaction of sex by gene marker groups affected $(P=0.0005)$ the numbers of bacterial colonies after addition of neutrophils. The numbers of bacterial colonies after addition of neutrophils and incubation periods in the ewes with the high resistant genotype was greater $(P=0.0003)$ than rams with the low resistant genotype. The numbers of bacterial colonies after addition of neutrophils and incubation periods in ewes with low resistant genotypes were greater $(P=0.0004)$ than rams with high resistant genotype. Comparing rams with the high resistant genotype with the low resistant ones, the number of bacterial colonies after addition of neutrophils and incubation periods was greater $(P<0.001)$ in rams with the low resistant genotypes. The number of bacterial colonies after addition of neutrophils decreased after 20,40 , and 60 min of incubation $(P<0.001$; Figure 9). The interaction of incubation time and gene marker groups $(P=0.25)$ and the interaction of sex and incubation time $(P=0.49)$ did not affects the numbers of bacterial colonies after addition of neutrophils. The interaction of sex, incubation time, and gene marker groups had no effect $(P=0.93)$ on numbers of bacterial colonies after addition of neutrophils. The number of bacteria in the primary bacteria stock without neutrophil addition was $2 \times 10^{7} / \mathrm{ml}$ and this number increased $(P<0.001)$ after $20\left(2.2 \times 10^{7} / \mathrm{ml}\right), 40\left(2.4 \times 10^{7} / \mathrm{ml}\right)$, and $60\left(2.6 \times 10^{7} / \mathrm{ml}\right)$ min of incubation. No bacterial colony growth was observed in control samples. 


\section{$\underline{\text { Discussion }}$}

The phagocytic efficiency of neutrophils in the high resistant gene marker group was greater than that of the low resistant gene marker group which can be a proof that pathogens drive genetic diversity at host loci involved in immunity to infectious disease. Studies exploring the genetic basis of pathogen resistance in the wild have focused almost exclusively on genes of the Major Histocompatibility Complex (MHC); the role of genetic variation elsewhere in the genome as a basis for variation in pathogen resistance has rarely been explored in natural populations (Turner et al., 2011).

Neutrophils in rams showed greater phagocytic efficiency than those in ewes. There is a minor difference between the neutrophils of rams and ewes. The cell nucleus of a neutrophil in ewes shows a small additional $\mathrm{X}$ chromosome structure, known as a "neutrophil drumstick" (Zucker-Franklin and Grossi, 2003). The X-chromatin (drumstick) is used in diagnosing major $\mathrm{X}$-related reproductive abnormalities and stunted growth in the animal industry (Bhatia and Shanker, 1984; Berepubo et al., 1993). Immune response is vigorous and more active in females compared to males, leading to the consequent increase in autoimmune conditions seen in the female population as well as differences in the immune response to pathogens and viruses. The paradigm of hormonal influence on immune response stipulates that estrogen enhances immune responses, while progesterone and androgens decrease them (Whitacre et al., 1999). Progesterone enhances chemotaxis and estrogen inhibits it, while testosterone had no modulating effect (Miyagi et al., 1992). Moreover, it should be considered that genes 
relevant to the immune system are located on autosomes, not on the $\mathrm{X}$ or $\mathrm{Y}$ chromosomes and these genes are also regulated in a gender-specific manner (Ellegren and Parsch, 2007) and therefore, sex differences in immune response are due to hormonal influences and genetics.

The neutrophil phagocytic capacity to engulf bacteria is affected when simple sugars are digested, and fasting strengthens the neutrophils phagocytic capacity to engulf bacteria. However, the digestion of normal starches has no effect (Sanchez et al., 1973). On the other hand, there are some factors that affect bacterial growth such as availability of nutrients, moisture, and temperature. A bacterial population growth curve includes four phases. 1) A lag phase in which the bacteria absorb nutrients, synthesize enzymes and prepare for cell division. The number of bacteria does not increase during the lag phase. 2) A logarithmic growth phase in which the bacteria multiply rapidly and the number of organisms doubles with each generation time. 3) A stationary phase during which the nutrients in the liquid medium are used up and the concentration of toxic waste products from the metabolizing bacteria build up, the rate of division slows, such that the number of bacteria that are dividing equals the number that are dying. 4) A death phase during which the concentration of toxic waste products continues to increase and the nutrient supply decreases. The microorganisms die at a rapid rate (Zwietering, 1990).

Some pathogenic bacteria are inherently able to resist the bactericidal components of host tissues, usually as a function of some structural property. Examples 
include the poly-D-glutamate capsule of Bacillus anthracis, the outer membrane of gram-negative bacteria, the waxy cell wall of pathogenic mycobacteria, and the intact lipopolysaccharides (LPS) of gram-negative pathogens. Bacterial pathogens have diverse strategies to avoid phagocytic engulfment and killing. They can block one or more of the steps in phagocytosis, thereby halting the process or avoiding the attention of phagocytes by invading or remaining confined in regions inaccessible to phagocytes, e.g. the lumens of glands, the urinary bladder, and surface tissues (unbroken skin). Some pathogens are able to avoid provoking an overwhelming inflammatory response. Additionally, some bacteria or their products inhibit phagocyte chemotaxis. Some pathogens can cover the surface of the bacterial cell with a component which is seen as "self" by the host phagocytes and immune system. Such a strategy hides the antigenic surface of the bacterial cell. Phagocytes cannot recognize bacteria upon contact and the possibility of opsonization by antibodies to enhance phagocytosis is minimized. Some bacteria employ strategies to avoid engulfment (ingestion) if phagocytes make contact with them. Resistance to phagocytic ingestion is usually due to a component of the bacterial cell surface (cell wall, or fimbriae, or a capsule). Some bacteria survive inside of phagocytes, either neutrophils or macrophages. Some intracellular parasites have special genetically-encoded mechanisms to get themselves into host cells that are nonphagocytic (Todar, 2008).

Intracellular parasites survive inside of phagocytes by virtue of mechanisms which interfere with the bactericidal activities of the host cell like inhibition of fusion of 
the phagocytic lysosomes (granules) with the phagosome. With some intracellular parasites, phagosome-lysosome fusion occurs, but the bacteria are resistant to inhibition and killing by the lysosomal constituents. Early escape from the phagosome vacuole is essential for growth and virulence of some intracellular pathogens. One obvious strategy in defense against phagocytosis is direct attack by the bacteria upon the professional phagocytes. Phagocytes may be killed by a pathogen before or after ingestion (Todar, 2008).

Invasiveness and toxigenesis are two broad qualities of pathogenic bacteria by which they cause disease. Invasiveness encompasses mechanisms for colonization (adherence and initial multiplication), production of extracellular substances which facilitate invasion and ability to bypass or overcome host defense mechanisms. $D$. nodosus, the major causative agent of ovine footrot, has type IV fimbriae which initially involve the promotion of close contact between bacteria and host cells. Type IV fimbriae mediated twitching motility is required for the subsequent translocation of the bacterium into a more anaerobic microenvironment, which is necessary for subsequent bacterial growth and extracellular protease production, ultimately leading to lesion formation. $D$. nodosus needs to produce extracellular proteases and exhibit twitching motility in order to be virulent (Kennan et al., 2011).

A neutrophil lifespan is about $5 \mathrm{~d}$ in the bloodstream and 1-4 $d$ in the connective tissue after activation. Neutrophils do not proliferate and have an estimated half-life of approximately 10-12 hours under in vitro culture conditions (Soehnlein, 2010). The 
short lifetime of neutrophils is an evolutionary adaptation that minimizes propagation of those pathogens that parasitize phagocytes because the more time such parasites spend outside a host cell, the more likely they will be destroyed by some component of the body's defenses, additionally, neutrophil antimicrobial products can also damage host tissues; their short life limits damage to the host during inflammation (Wheater et al., 2002). In this study the average viability of extracted neutrophils was $95 \%$ in each individual specimen at inoculation and the longest incubation time was $60 \mathrm{~min}$.

Considering all the factors affecting bacterial growth and phagocytic rate, in this study, the number of bacteria in the stock without neutrophil increased during 20,40 and 60 min of incubation which provides evidence for viability of bacteria, and after addition of neutrophils, the number of bacterial colonies decreased significantly which is evidence of phagocytic activity. Since there was no significant difference in the percentage of neutrophils in whole blood between genotypes and between rams and ewes, it can be concluded that the phagocytic efficiency in Katahdin sheep in the high resistant gene marker group is greater than the ones in the low resistant gene marker (Azarpajouh et al., 2014). 
Figure 7: Comparison of the numbers of bacterial colonies after addition of neutrophils and incubation periods in the low resistant gene marker group (LR) vs. the high resistant gene marker group (HR; $P=$ 0.0006).

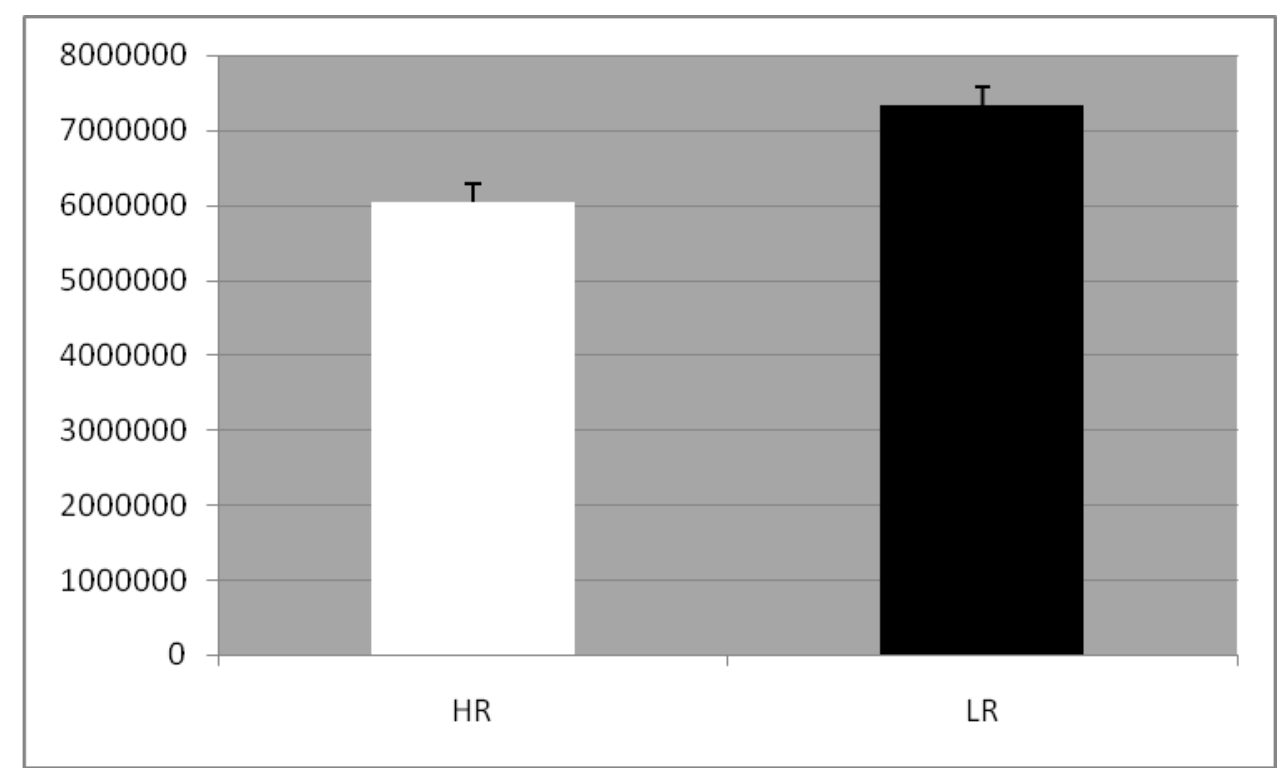


Figure 8: Comparison of the numbers of bacterial colonies after addition of neutrophils and incubation periods in ewes vs. rams $(P=0.02)$.

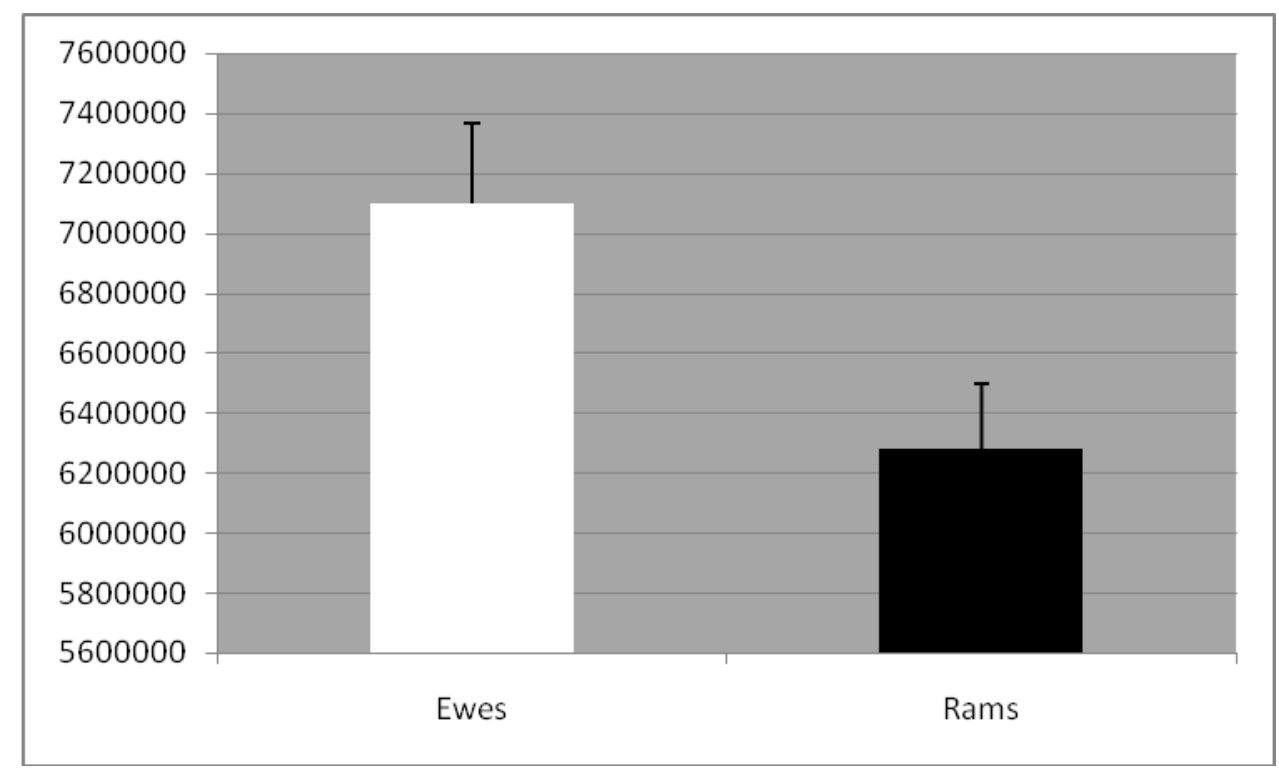


Figure 9: Comparison of the number of bacterial colonies after addition of neutrophils and after 20, 40, and $60 \mathrm{~min}$ of incubation $(P<0.001)$.

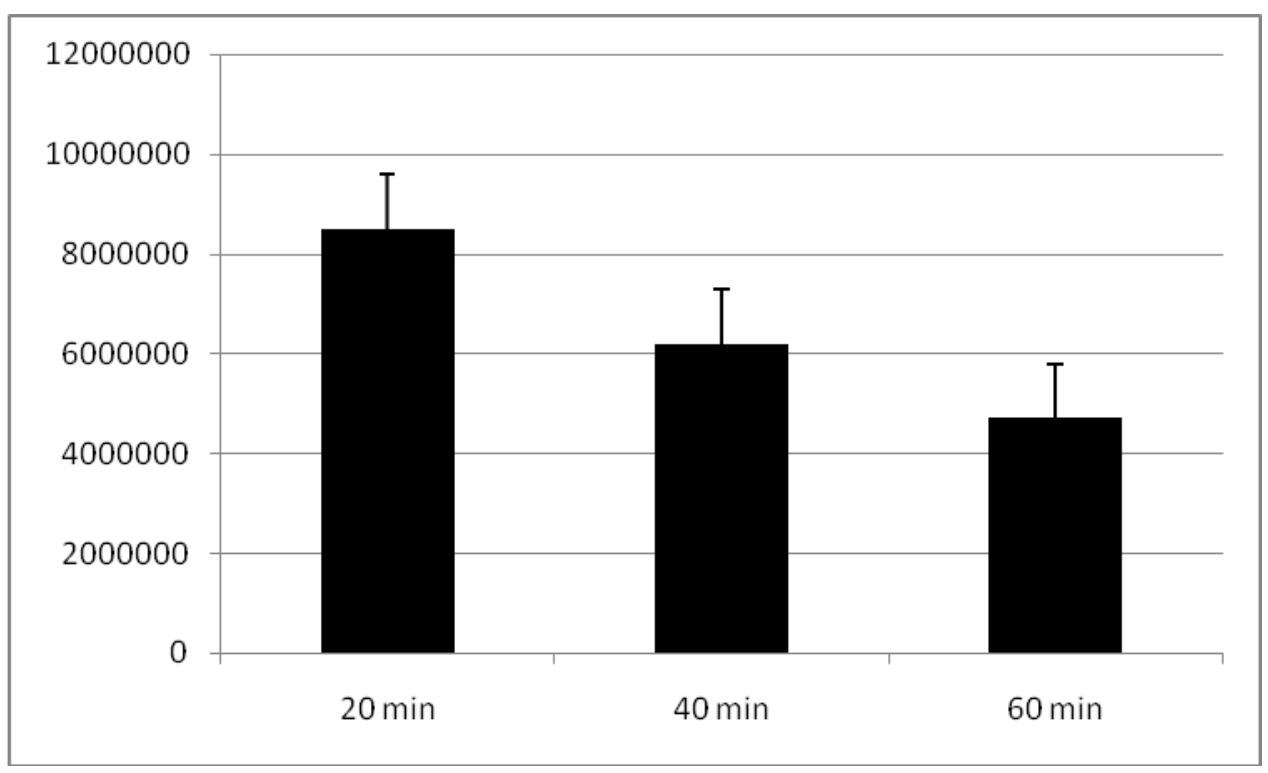




\title{
CHAPTER V
}

\section{COMPARISON OF ULTRASTRUCTURAL CHANGES CAUSED BY}

\section{DICHELOBACTER NODOSUS IN STRATUM CORNEUM OF HOOF}

\section{TISSUE OF SHEEP}

\begin{abstract}
Bacterial invasion of the stratum corneum causes degenerative processes and dissociation of epidermal cells following edema and extravasation. Dichelobacter nodosus penetration into the stratum corneum requires the adhesive activity of type IV fimbriae and is accompanied by sinus formation. Generally, black-pigmented hooves areconsidered to be more resistant than white-colored hooves; therefore the objective of this study was to compare the ultrastructural changes caused by bacterial infection in the epidermal layer of black vs. white pigmented hooves. Six white and black hoof tissue samples ( $n=3$ each) collected after hoof trimming were cut using a metal cork borer with diameter and thickness of $1 \mathrm{~mm}$. The samples were washed and dipped in
\end{abstract}


Isopropyl Alcohol 70\% then examined with Wolfe ${ }^{\circledR}$ StereoPro ${ }^{\mathrm{TM}}$ Stereomicroscopes. Two strains of $D$. nodosus stored at $-80^{\circ} \mathrm{C}$ in a PBS solution were revived by transferring to nutrient broth-based culture tubes and incubated at $37^{\circ} \mathrm{C}$ in anaerobic jars overnight. The samples and the bacteria were transferred to the beef broth medium and incubated at $37^{\circ} \mathrm{C}$ in anaerobic jars for $6 \mathrm{~d}$. No bacteria were inoculated in the control groups (white and black hoof tissue samples). After primary fixation with $2.5 \%$ glutaraldehyde and post fixation with $1 \%$ osmium tetroxide, specimens were dehydrated using a graded series of ethyl alcohol (70\% for $15 \mathrm{~min}, 95 \%$ for $15 \mathrm{~min}$, and 3 changes of $100 \%$ for 10 min each) and then dried using a commercially available critical point drying apparatus. The specimens were mounted on aluminum stubs with adhesive tabs and sputter coated for 3 min. Finally, using an Environmental Scanning Electron Microscope, images were taken of the specimens. Sinus formation was observed in both white and black hoof tissues. In addition, some bacteria were observed in both white and black hoof tissues in the control group which can be the normal inhabitant of external and internal environments. There was no significant relationship between the tissue pigment and the ultrastractural changes in tissue.

\section{Introduction}

The hoof is a structure surrounding the distal phalanx of the third digit which provides protection to the distal limb and is formed by keratinisation of the epithelial layer and modification of the underlying dermis. The thickened cornified keratin in the 
epidermis is referred to as horn. It makes up the outer surface of the hoof and is particularly resistant to mechanical and chemical damages. The hoof wall forms a major portion of the protective outer surface of the foot and is the primary weight bearing structure (Sisson et al., 1975).

The hoof has an epidermis and a connective tissue corium which is continuous with the epidermis and dermis of the skin. The epidermis consists of a thin layer of stratum basale and stratum spinosum and a thick layer of stratum corneum. Three layers of the hoof wall include the stratum tectorium, stratum medium and stratum lamellatum (Eurell, 2004).

The stratum corneum is the outermost layer of the epidermis, consisting of dead cells (corneocytes). Stratum corneum forms a barrier to protect underlying tissue from infection, dehydration, chemicals and mechanical stress (Ovaere et al., 2009). The stratum corneum of the inter-digital skin consists of a dense layer of highly stratified squamous cells. When healthy and dry, it is an effective barrier to growth and penetration by bacteria. The development of bacterial infection either in the stratum corneum or deeper layers of the epidermis requires either extensive dehydration of the stratum corneum or its breaching by mechanical forces (Egerton, 1989).

D. nodosus invasion of the stratum corneum and stratum granulosum causes degenerative process and dissociation of epidermal cells following edema and extravasation. $D$. nodosus, the main cause of ovine footrot, penetrates into the stratum 
corneum using the adhesive activity of type IV fimbriae and causes sinus formation (Egerton, 1989).

Generally, black-pigmented hooves are considered to be more resistant than white-colored hooves; therefore, the objective of this study was to compare the ultrastructural changes caused by bacterial infection in the epidermal layer of white vs. black pigmented hooves.

\section{Materials and Methods}

Six white and black hoof tissue samples ( $n=3$ each) were collected after hoof trimming from sheep with normal hooves (foorot score 0) and transferred to the lab. Samples were cleaned and scrubbed, then using a metal cork borer, hoof tissue specimens with diameter and thickness of $1 \mathrm{~mm}$ were cut from deeper parts of tissue to make sure no bacteria were present. The samples were washed and dipped in Isopropyl Alcohol $70 \%$ and then examined with Wolfe ${ }^{\circledR}$ StereoPro ${ }^{\mathrm{TM}}$ Stereomicroscopes.

Two D. nodosus strains, ATCC 25549 (US) and ATCC 31545 (Aust) lyophilized bacteria stock were acquired from American Type Culture Collection (ATCC, Manassas, Virginia). Two strains of the bacteria stock (D. nodosus), stored at $-80^{\circ} \mathrm{C}$ in a PBS solution, and were revived by transferring to a nutrient broth-based culture tube separately and incubating at $37^{\circ} \mathrm{C}$ in anaerobic jars overnight. Black and white hoof tissue samples and the two bacteria strains were transferred to the beef broth medium 
separately and incubated at $37^{\circ} \mathrm{C}$ in anaerobic jars for $6 \mathrm{~d}$. No bacteria were inoculated in the control groups (white and black hoof tissue samples).

Samples were fixed with $2.5 \%$ glutaraldehyde for $24 \mathrm{~h}$ at $4^{\circ} \mathrm{C}$. After initial fixation, the specimens were rinsed several times with PBS for $15 \mathrm{~min}$, followed by post fixation with $1 \%$ osmium tetroxide in $0.1 \mathrm{M}$ Phosphate Buffer for $1 \mathrm{~h}$. After rinsing with PBS for 15 min the specimens were dehydrated using a series of graded ethyl alcohol ( $70 \%$ for $15 \mathrm{~min}, 95 \%$ for $15 \mathrm{~min}$, and 3 changes of $100 \%$ for $10 \mathrm{~min}$ each). Tissues were dried using a commercially available critical point drying apparatus (Tousimis Autosamdri R-815). Specimens were mounted on aluminum stubs with adhesive tabs and sputter coated with a thin layer of platinum for 3 min using an Emitech K575x Sputter Coater in Electron Microscopy Core at University of Missouri. The specimens were then ready for viewing and photographing with the Environmental Scanning Electron Microscope (Quanta 600F ESEM). The images of treated and control samples were used to compare the damage caused by bacteria to epidermal layer of hoof tissue.

\section{$\underline{\text { Results }}$}

Control samples represented the normal ultrastructure of the hoof. There were no sinus formation and the laminae structure was intact (Figure 10). In some cases the individual round shaped bacteria (coco bacillus) with no pili or fimbriae were present 
along with the hoof surface with no observable damages which can be the normal inhabitant of the hoof tissue or external environment.

In treated samples colonies of rod shaped $D$. nodosus with type IV fimbriae were observed attaching to hoof tissues (Figure 11). Both U.S. and Australian strains of $D$. nodosus, caused sinus formation in stratum corneum of white and black hoof tissues. The sinus formation was mostly observed close to the bacterial colonies with fimbriae which provides evidence for the essential role of fimbriae as a virulent factor of $D$. nodosus (Figures 12 and 13). There was no relationship between the tissue pigment, bacteria strain and the ultrastractural changes in tissue; therefore there was no difference between the resistance of white vs. black hoof to bacterial invasion.

\section{Discussion}

The scanning electron microscope provided an easy and reproducible technique for studying the changes in hoof horn structure. The observations revealed sinus formation in the stratum corneum of hoof tissue caused by Australian and US strains of D. nodosus.

Common pili also known as fimbriae are usually involved in specific adherence of procaryotes to surfaces in nature and are considered as major determinants of bacterial virulence because they allow pathogens to attach to tissues, to colonize, and to resist attack by phagocytic white blood cells. At the end of each fimbria there are 
special proteins called adhesins, which vary by type of bacteria, and these molecules allow bacteria with fimbriae to adhere to the receptor proteins on the surface of host epithelial cells (Todar, 2008).

Type IV fimbriae, extracellular proteases, and several genomic islands, are potential virulence factors of $D$. nodosus (Billington et al., 1996; Rood, 2002). Type IV fimbriae are major surface antigens of $D$. nodosus which mediate twitching motility that enables bacteria to move along solid surfaces, attach to hoof laminae (Kennan et al., 2001), and facilitate the pathogenesis of footrot.

Some bacterial colonies with no pili or fimbriae were observed in both control and treated samples, which can be the normal inhabitant of internal or external environments. Usually the healthy inter-digital skin and stratum corneum act as natural barriers against bacteria, but the mean daily temperature above $10^{\circ} \mathrm{C}$ following two to three months of rainfall exceeding about $50 \mathrm{~mm}$ per month may cause maceration in inter-digital skin and lead to footrot (Abbott and Lewis, 2005).

In this study, bacteria and hoof tissue were incubated for a $6 \mathrm{~d}$ period in an anaerobic jar simulating the natural condition under which footrot occurs. It is notable that $D$. nodosus cannot survive longer than a few days outside the feet of ruminants (Beveridge, 1941; Laing and Egerton, 1981), and it makes eradication of the disease from flocks possible. 
Al-Jashamy et al. (2008) using transmission electron microscopy, showed that ultrastructural changes in virulent footrot were mainly found in the stratum basal layer and intracellular space, where basal cells showed degenerative and necrotic changes. In the current study, a scanning electron microscope was used to investigate the changes caused by bacteria in the epidermal layer of the hoof tissue in cases of benign, intermediate and virulent footrot.

Black hooves are not more resistant to damage cause by $D$. nodosus than white hooves as the damage caused by bacteria in both hoof white and black hoof tissue were not different. The dissociation of epidermal cells and sinus formation in stratum corneum is caused by type IV fimbriae and extracellular protease of $D$. nodosus. The protease activity of the two strains of $D$. nodosus was determined using gelatin test (explained in chapter 3 ) and the type IV fimbrae was observed in the SEM images. Since D. nodosus is a normal inhabitant of ruminant feet and can cause footrot in cases of maceration or injuries in hoof tissue, it is essential to keep animals in a dry healthy bedding system to prevent footrot and other hoof diseases. 
Figure 10: Normal hoof structure in control samples.

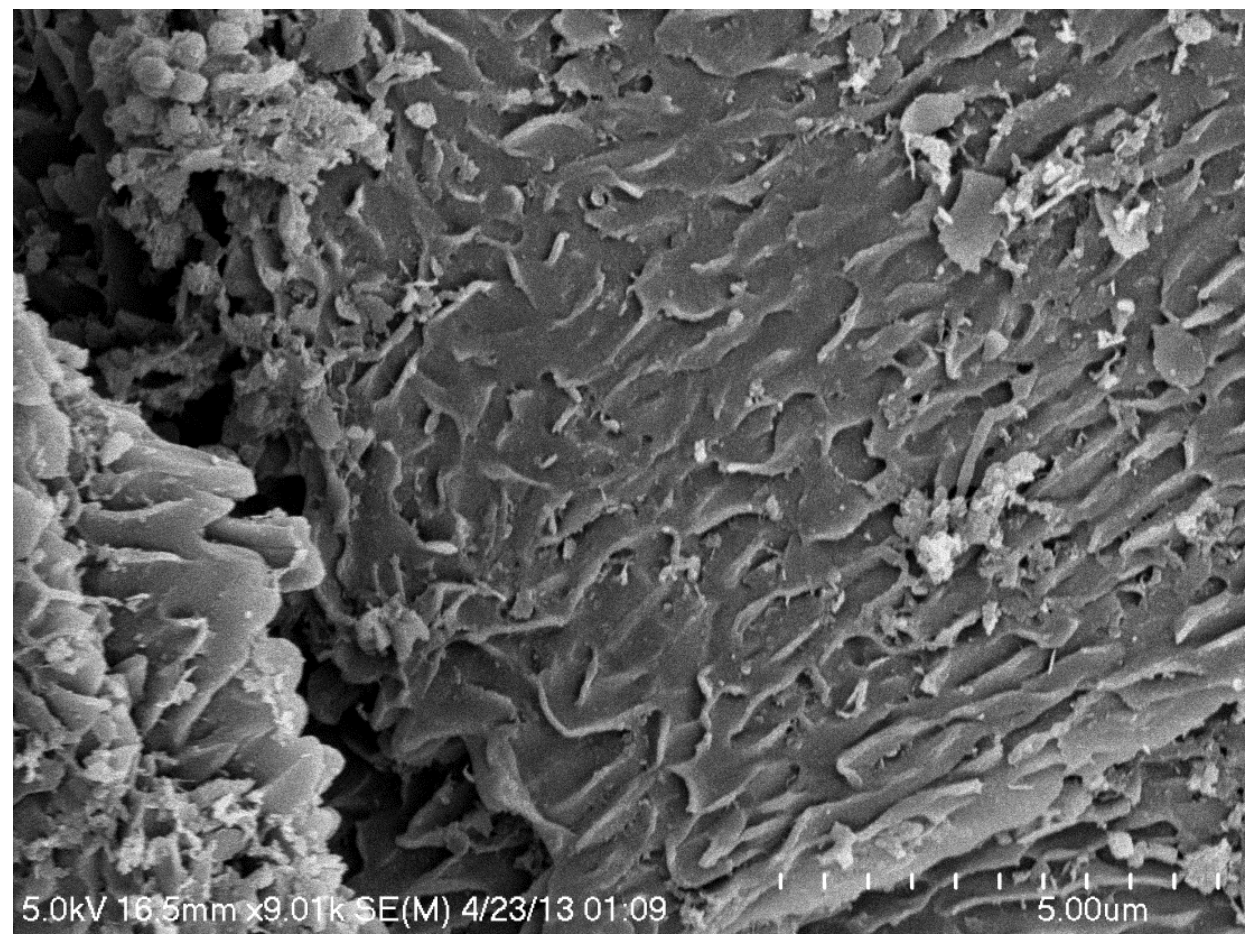


Figure 11: Colonies of rod shaped $D$. nodosus with type IV fimbriae.

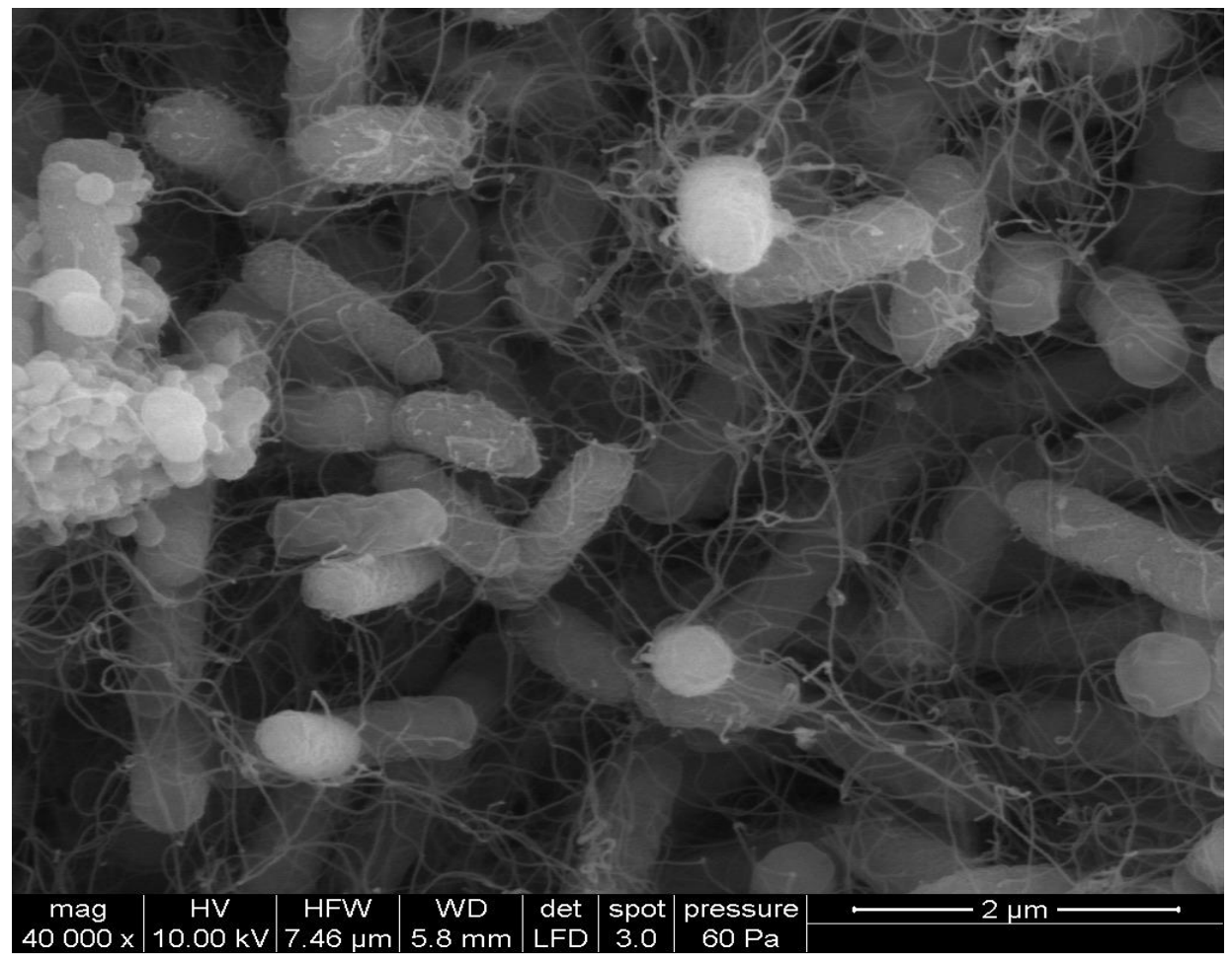


Figure 12: Black hoof tissue invaded by $D$. nodosus.

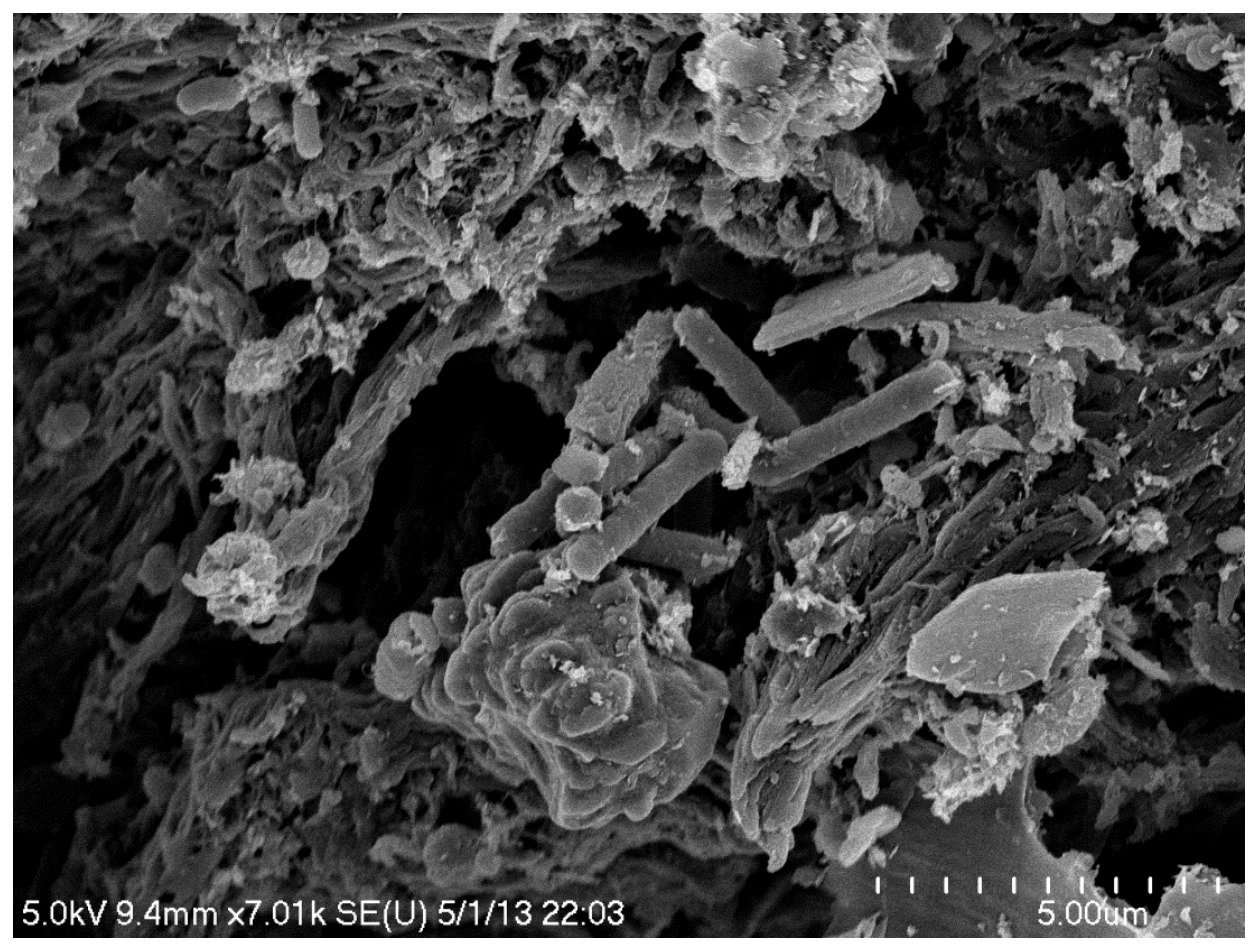


Figure 13: White hoof tissue invaded by $D$. nodosus.

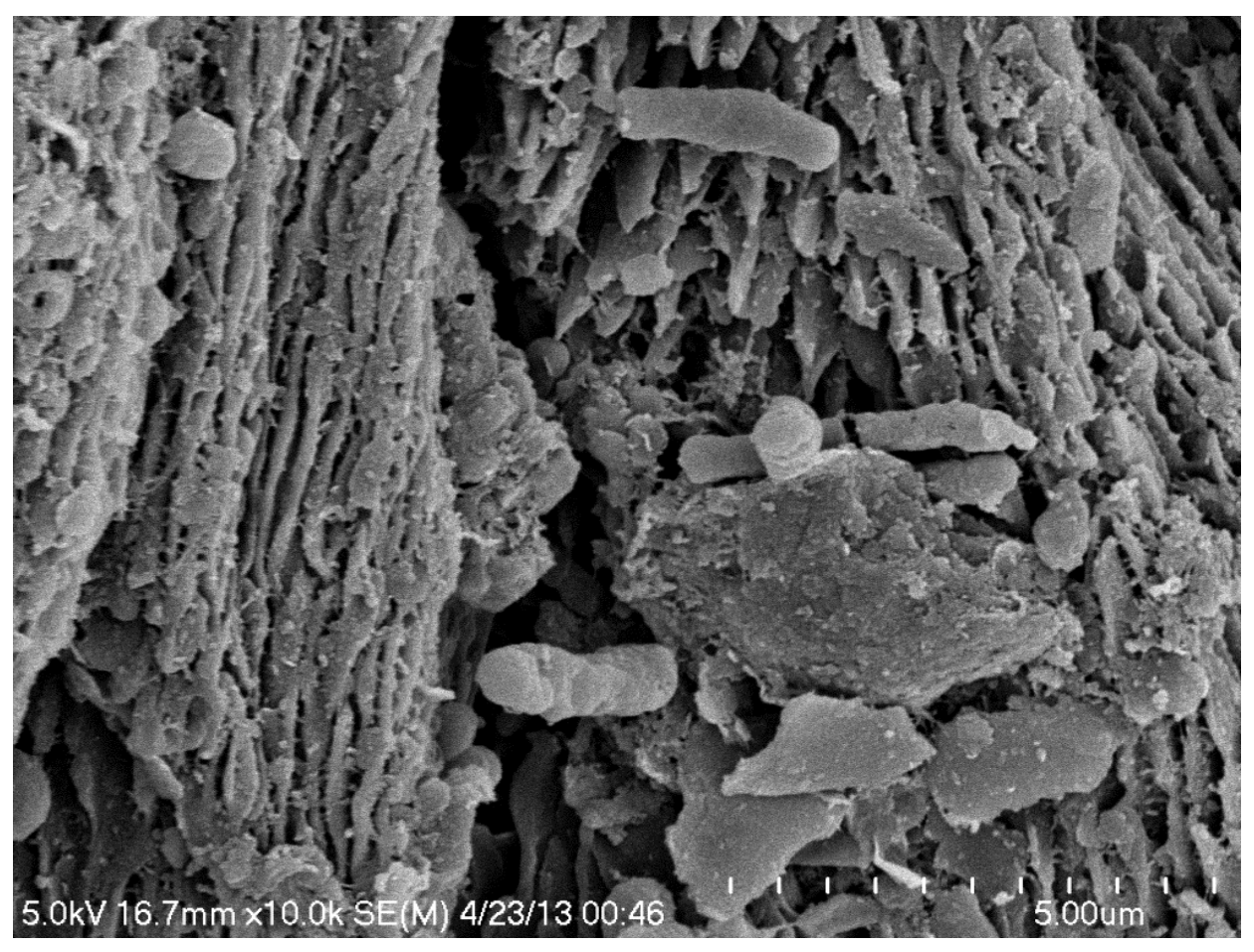




\section{CHAPTER VI}

\section{GENERAL DISCUSSION}

At the end of the footrot pathogenic challenge, all animals in the control group had footrot scores of zero which suggests that there was no natural infection from the environment. Twelve out of 34 animals in the treatment group had footrot scores of 1 and 2 representing scald, inter-digital skin inflammation, inter-digital dermatitis, and necrotizing inflammation of inter-digital skin. Footrot scores 3 and 4 were not observed in animals, which could have been due to low potency of the inoculated bacteria. Footrot gene marker score, sheep breed, and hoof color did not affect footrot score at the end of the trial.

$D$. nodosus and F. necrophorum were not isolated from culture swabs of interdigital space of the feet of ewes at the end of trial. Protease activity of $D$. nodosus before and after 8 and 16 min of incubation in $68^{\circ} \mathrm{C}$ was proved by presence of the clear zones of proteolysis around inoculated wells in the gelatin test. 
Body weight loss and decrease in BCS of the ewes at the end of trial might be due to stress induced during trial, since animals in the treatment group lost more weight. The IgG level in sera remained in the normal range $(7.6-40 \mathrm{mg} / \mathrm{ml})$ in both control and treatment groups because no active infection happened in animals and the higher level of IgG in the treatment group might be due to bacteria inoculation and higher stress perception (fitting plastic boots, bacteria inoculation).

The phagocytic efficiency of neutrophils in the high resistant gene marker group was greater than the low resistant gene marker group. Moreover, the phagocytic efficiency of neutrophils in rams was greater than those of ewes. It could be considered that sex differences in immune response are due to hormonal influences and genetics.

Considering all the factors affecting bacterial growth and phagocytic rate in this study, increase in the number of bacteria in the stock without neutrophils during incubation provides evidence of viability of bacteria, and the decrease in the number of bacterial colonies after addition of neutrophils provides evidence of phagocytic activity of neutrophils. Since there was no significant difference in the percentage of neutrophils in whole blood between genotypes and between rams and ewes, it can be concluded that the phagocytic efficiency in Katahdin sheep in the high resistant gene marker group is greater than the ones in the low resistant gene marker.

In the current study, a scanning electron microscope (SEM) was used to investigate the changes caused by bacteria in the epidermal layer of the hoof tissue in cases of benign, intermediate, and virulent footrot. Changes in hoof horn structure were 
observed and revealed sinus formation in the stratum corneum of hoof tissue caused by Australian and U.S. strains of D. nodosus. There were some bacterial colonies with no pili or fimbriae in both treated and control samples, which can be the normal inhabitant of internal or external environment.

There was no difference in damage caused by bacteria in the epidermal layer of black vs. white hoof tissue. Additionally in the footrot pathogenic challenge, hoof color had no effect on the severity of footrot and footrot score. Therefore; unlike the general belief, black hooves were not more resistant to damage caused by $D$. nodosus than white hooves and the dissociation of epidermal cells and sinus formation in stratum corneum was caused by type IV fimbriae and extracellular protease of $D$. nodosus. Because $D$. nodosus is a normal inhabitant of ruminant feet and major cause of ovine footrot in cases of maceration or injuries in hoof tissue, it is essential to keep animals in a dry healthy bedding system to prevent footrot and other hoof diseases.

D. nodosus protease activity, which is an essential virulent factor, was observed in the SEM study and by the gelatin test, by causing sinus formation in hoof tissue and clear zones of proteolysis around inoculated wells, respectively; however, no virulent footrot cases were observed during the footrot pathogenic challenge, which can be further evidence of footrot resistance in the Katahdin sheep breed.

The footrot gene marker test is a helpful method to distinguish and select animals with higher resistance to footrot without being exposed to an infection challenge in order to evaluate resistance or susceptibility to the disease. This test is used 
predominantly on sires and rams as these have greater genetic influence on flocks than ewes and resorting to such genetic selection approaches can potentially reduce antibiotic drugs use for food animals. 


\section{Literature cited}

Abbott, K.A., Lewis, C.J., 2005. Current approaches to the management of ovine footrot. Vet J. 169, (1), 28-41.

Adams, L.G., Templeton, J.W., 1998. Genetic resistance to bacterial diseases of animals. Rev Sci Tech. 17(1):200-19.

Aliyu, S.H., Marriott, R.K., Curran, M.D., 2004. Real-time PCR investigation into the importance of Fusobacterium necrophorum as a cause of acute pharyngitis in general practice. J Med Microbiol 53 (Pt 10): 1029-35.

Al-Jashamy, Jasni, S., 2008. Ultrastructural changes of the skin stratum basal layer and basement membrane in ovine footrot disease. Annals of Microscopy. 8, 36-41.

Alwan, M., 1983. Studies of the flock mating performance of Booroola Merino crossbred ram lambs and the foot conditions in the Booroola Merino crossbreds and Perendale sheep grazed on hill country. M. Agric. Sci. Thesis, Massey University.

Andersson, L., 2001. Genetic dissection of phenotypic diversity in farm animals. Nat. Rev. Genet. 2:130-138.

Archibald A.L., Bishop S.C., 2006. State-of-Science Review - Host Genetics and Engineering: the genetics of host responses to infectious diseases in farmed animals. In Foresight project 'Infectious Diseases: preparing for the future'. Department of Trade and Industry, UK; S11.

Axford, R.F.E., Bishop, S.C., Nicholas, F.W., Owen, J.B., 2000. Breeding for disease resistance in farm animals. 2nd edition. CABI publishing.

Baker, R.L., Clark, J.N., Harvey, T.G., Meyer, H.H., (1986). Inheritance of foot and jaw abnormalities in sheep. Proceedings of the New Zealand Society of Animal Production 46: 93-100.

Azarpajouh, S., Wuliji, T., Bax, A., 2014. Comparison of white blood cell phagocytic efficiency in two genotypes of Katahdin sheep. J. Anim. Sci. Vol. 92 E-Suppl. 2/J. P.366.

Beckmann, J.S., Soller, M., 1986. Restriction fragment length polymorphisms in plant genetic improvement. Oxford Surv Plant Mol Cell Biol 3:197-246. 
Berepubo, N.A., Pinherio, L.E., Basrur, P.K., 1993. Biological significance of Xchromosomes inactivation pattern in sub fertile cows carrying an $\mathrm{X}$-autosome translocation. Discov. Innov. 5: 57-62.

Beveridge, W.I.B., 1934. Footrot in sheep. Skin penetration by Strongyloides larvae as a predisposing factor. Australian Vet J, 10, 43-51.

Beveridge W.I.B., 1935. Journal of the Council for Scientific and Industrial Research Australia, 8, 308.

Beveridge, W.I.B., 1941. Footrot in sheep: a transmissible disease due to infection with Fusiformisnodosus (n.sp.). Journal of the Council for Scientific and Industrial Research. Bulletin Number 140.

Beveridge, W.I.B., 1967. Disease caused by non-sporing anaerobes: ovine footrotnecrobacillosis. Bulletin Office International Epizootics 67, 1597-1601.

Bhatia, S.K., Shanker, V., 1984. Sex chromatin test in bovines: A cytodiagnostic tool for detection of poor breeders at birth. Proc. 10th International Congress of Anim. Reprod. and A.I., Vol. 3, 526.

Billington, S. J., Johnston,J. L., Rood, J.I., 1996. Virulence regions and virulence factors of the ovine footrot pathogen, Dichelobacter nodosus. FEMS Microbiol. Lett. 145:147-156.

Bishop, S.C., 2005. Disease resistance: genetic. W.G. Pond, A.W. Bell (Eds.), Encyclopedia of Animal Science, Marcel Dekker Inc., New York, 288-290.

Bishop, S.C., MacKenzie, K.M., 2003. Genetic management strategies for controlling infectious diseases in livestock populations. Genet. Sel. Evol. 35, (Suppl. 1), S3-S17.

Bishop, S.C., Morris, C.A., 2007. Genetics of disease resistance in sheep and goats. Small Ruminant Research. Vol 70, (1), 48-59.

Bishop, S.C., Stear, M.J., 2003. Modeling of host genetics and resistance to infectious disease: understanding and controlling nematode infections. Veterinary Parasitology 115:147-166.

Bishop, S.C., Woolliams, J.A., Wallis, I.P., 2006. Developing genetic epidemiological models for bacterial infections with environmental contamination. 8th World congress on genetics applied to livestock production: 13-18 Aug. Belo Horizone, Brazil: 15-23. 
Black's Veterinary Dictionary (Edward Boden, Editor), 1995. A\&C Black Publishers Limited. 18th ed., 816.

BOA. 1999. The use of drugs in food animals: benefits and risks. Washington DC. Board on Agriculture, National Academies Press.

Boopathi, N.M., 2013. Genetic Mapping and Marker Assisted Selection, Basics, Practice and Benefits. Springer India, 173-186.

Breeds of Livestock, 1995. Oklahoma State University Board of Regents. http://www.ansi.okstate.edu/breeds/sheep/

Bulgin, M.S., Lincoln, S.D., Parker, C.F., South, P.J., Dahmen, J.J., Lane, V.M., 1988. Genetic-associated resistance to foot rot in selected Targhee sheep. Journal of the American Veterinary Medicine Association. 192, 512-515.

Burke, J.M., Parker, C.F., 2007. Effect of breed on response to footrot treatment in mature sheep and lambs. Small Ruminant Research, 71, 165-169.

Casa, A. M., Brouwer, A., Nagel, A.,Wang, L., Zhang, Q., Kresovich, S., Wessler, S. R., 2000. The MITE family Heartbreaker ( $\mathrm{Hbr}$ ): Molecular markers in maize. Proc. of the National Academy of Sciences. 97, 10083-10089.

Claxton, P.D., 1989. Antigentic classification of Bacterioidesnodosus. In: Egerton, J.R. Yong, W.K., Riffkin, G.G. (Eds) Footrot and foot abcesses of ruminants. CRC Press, 155166.

Cockett, N., Bishop, S.C., Davies, G., Hadfield, T., Eng, S., Miller, J., 2005. Use of QTL to Determine Parasite Resistance in Sheep. Ann. Meet. Amer. Soc. Anim. Sci., July 24-28. Cincinnati, Ohio, USA.

Cohen, S., Burns, R.C., 2002.Pathways of the Pulp, 8th Edition. St. Louis: Mosby, Inc. 465. Collins, J., Conington, J., 2005, Sheep Easy Breeding Group, SAC, Scotland.

Coltman, D.W., Wilson, K., Pilkington, J.G., Stear, M.J., Pemberton, J.M., 2001. A microsatellite polymorphism in the gamma interferon gene is associated with resistance to gastrointestinal nematodes in a naturally-parasitized population of Soay sheep. Parasitol. (122) 571-582. 
Conington, J., Hosie, B., Nieuwhof, G. J., Bishop, S. C., Bünger, L., 2008. Breeding for resistance to footrot - the use of hoof lesion scoring to quantify footrot in sheep. Vet Res Commun . 32:583-589.

Cumlivski, B., 1988. Resistance of sheep kept together of the breeds Kent (Romney Marsh), Lincoln, Cotswold and Leicester. In: Proceedings of the 3rd world congress on sheep and beef cattle breeding, Paris, France, Vol 1: 643-645.

Curtis, C.R., Erb, H.N., Sniffen, C.J., Smith, R.D., Powers, P.A., Smith, M.C., White, M.E., Hillman, R.B., Pearson, E.J., 1983. Association of parturient hypocalcemia with eight periparturient disorders in Holstein cows. J Am Vet Med Assoc. 183(5):559-61.

Dale, D.C., Boxer, L., Liles, W.C., 2008. The phagocytes: neutrophils and monocytes. Blood. 15;112(4):935-45.

Darvasi, A., 1998. Experimental strategies for the genetic dissection of complex traits in animal models. Nature Genetics 18, 19-24.

Davies, G., Stear, M.J., Benothman, M., Abuagob, O., Kerr, A., Mitchell, S., Bishop, S.C., 2006. Quantitative trait loci associated with parasitic infection in Scottish Blackface sheep. Heredity (Edinb) Journal; 96 (3) : 252-8.

Deane, H.M., Jensen, J., 1955. The pathology of contagious footrot in sheep. American Journal of Veterinary Research, 16, 203.

Dekkers, J. C. M., Hospital, F., 2002. The use of molecular genetics in improvement of agricultural populations. Nat. Rev. Genet. 3:22-23.

Delves, P. J., Martin, S. J., Burton, D. R., Roit, I. M., 2006. Roitt's Essential Immunology (11th ed.). Malden, MA: Blackwell Publishing, 6-7.

Depiazzi, L.J., Roberts, W.D., Hawkins, C.D., Palmer, M.A., Pitman, N.C., McQuade, N.C., Jelinek, P.D., Devereaux, D.J., Rippon, R.J., 1998. Severity and persistence of footrot in Merino sheep experimentally infected with a protease thermostable strain of Dichelobacter nodosus at five sites. Australian Vet J, 76, 32-38.

Egerton, J.R., 2002. Management of footrot in small ruminants. Proc. of the 12th International Symposium on Lameness in Ruminants, 9th - 13th Jan, Orlando, FL, USA, 139-146.

Egerton, J.R., 1989. Footrot of Cattle, Goats, and Deer. Footrot and Foot Abscess of Ruminants. 47-56. 
Egerton J.R, Roberts, D.S., Parsonson, I.M. (1969). The etiology and pathogenesis of ovine footrot. A histological study of the bacterial invasion. J Comp Path 79: 207-215.

Egerton, J.R., Parsonson, I.M., 1969. Benign footrot - a specific inter-digital dermatitis of sheep associated with infection by less proteolytic strains of Fusiformisnodosus. Australian Vet J, 45, 345-349.

Egerton, J.R., Raadsma, H.W., 1993. Unresolved questions about footrot eradication. Wool Technology and Sheep Breeding, 41, 99- 107.

Egerton, J.R., Roberts, D.S., 1971. Vaccination against ovine footrot. J of Comparative Pathology, 81, 179-185.

Egerton, J.R., Roberts, D.S., Parsonson, I.M., 1969. The etiology and pathogenesis of ovine foot-rot. I. A histological study of the bacterial invasion. J of Comparative Pathology 79, 207- 216.

Egerton, J.R., Thompson, J.J., Merritt, G.C., 1979. Comparison of oil-adjuvant and alumprecipitated Bacteroides nodosus vaccines in treatment of footrot. Vet Rec, 104, 98-100.

Egerton, J.R., Thorley, C.M., 1981. Effect of alum-precipitated or oil-adjuvant Bacteroidesnodosus vaccines on the resistance of sheep to experimental footrot. Research in Vet Sci. 30, 28-31.

Ellegren, H., Parsch, J., 2007. The evolution of sex-biased genes and sex-biased gene expression. Nat Rev Genet; 8:689-98.

Emery, D.L., Stewart, D.J., Clark, B.L., 1984. The comparative susceptibility of five breeds of sheep to footrot. Australian Vet J, 61: 85-88.

Ernst, J. D., Stendahl, O., 2006. Phagocytosis of Bacteria and Bacterial Pathogenicity. New York: Cambridge University Press, 7-10, 186.

Escayg, A.P., Hickford, J.G.H., Bullock, D.W., 1997. Association between alleles of the ovine major histocompatibility complex and resistance to footrot. Research in Vet Sci, 63 (3): 283-287.

Eurell, J.A., 2004. Veterinary Histology. Teton New Media. Chapter 35, 71. 
Falconer, D.S., 1981. Introduction to quantitative genetics, (2nd ed.). Longman, London, UK.

Falconer, D. S., Mackay, T. F. C., 1996. Introduction to Quantitative Genetics, 4th ed. (London, Prentice Hall).

FAO. 1999. Opportunities for incorporating genetic elements into the management of farm animal diseases: policy issues, by S. Bishop, M. de Jong \& D. Gray. Background Study Paper Number 18. Commission on Genetic Resources for Food and Agriculture. Rome.

FAO. 2007. The State of Agriculture Biodiversity in the Livestock Sector, Section E: Animal genetic resources and resistance to disease. 101-112.

Gelderman, H., 1975. Investigation on inheritance of quantitative characters in animals by gene markers. I. Methods. Theoretical and Applied Genetics, 46, 300-19.

Ghimire, S.C., Egerton, J.R., Dhungyel, O.P., 1999. Transmission of virulent footrot between sheep and goats. Australian Vet J, Vol 77 (7), 450- 453.

Ghimire, S.C., Whittington, R.J., Dhungyel, O.P., Joshi, H.D., Egerton, J.R., 2002. Diagnosis of footrot in goats: application of ELISA tests for response to antigens of Dichelobacter nodosus. Vet Micro, 87, 237-251.

Glynn, Y., 1993. Benign footrot--an epidemiological investigation into the occurrence, effects on production, response to treatment and influence of environmental factors. Australian Vet J, 70, 7-12.

Graham, N.P.H., Egerton, J.R., 1968. Pathogenesis of ovine footrot: the role of some environmental factors. Australian Vet J, 44, 235-240.

Greer, G., 2007. Impacts of the footrot gene-marker test on New Zealand sheep farming. Lincoln University's Agribusiness and Economics Research Unit, (AERU).

Gregory, T.S., 1939. Footrot in sheep. Australian Vet J, 15, 160-167.

Guimarães, E.P., Ruane, J., Scherf, B.D., Sonnino, A., Dargie, J.D., 2007. Marker-Assisted Selection, current status and future perspectives in crops, livestock, forestry and fish. The Food and Agriculture Organization of the United Nations, 5.

Gupta, P. K., \& Rustgi, S., 2004. Molecular markers from the transcribed/expressed region of the genome in higher plants. Functional and Integrative Genomics, 4, 139-162. 
Hall, J. A., Sendek, R. A., Chinn, R. M., Bailey, D. P., Thonstad, K. N., Wang, Y., Forsberg, N. E., Vorachek, W. R., Stang, B. V., Van Saun, R.J., Bobe, G., 2011. Higher whole-blood selenium is associated with improved immune responses in footrot-affected sheep. Vet Res. 42(1): 99.

Hampton, M.B., Vissers, M.C., Winterbourn, C.C., 1994. A single assay for measuring the rates of phagocytosis and bacterial killing by neutrophils. J. Leukoc. Biol. 55 (2): 147-52.

He, B., Santamaria, R., Xu, W., Cols, M., Chen, K., Puga, I., Shan, M., Xiong, H., Bussel, J.B., Chiu, A., Puel, A., Reichenbach, J., Marodi, L., Döffinger, R., Vasconcelos, J.,Issekutz, A., Krause, J., Davies, G., Li, X., Grimbacher, B., Plebani, A., Meffre, E., Picard, C., Cunningham-Rundles, C., Casanova, J.L., Cerutti, A., 2010. The transmembrane activator TACl triggers immunoglobulin class switching by activating $B$ cells through the adaptor MyD88. Nat. Immunol. 11, 836-845.

Henry, R. J., 2006. Plant Conservation Genetics (New York, Haworth Press).

Hickford, J., 2000. Development of a sustainable method of natural footrot control. Report to the NZ Meat Research and Development Council, Lincoln University.

Hickford, J.G.H., Zhou, H., Slow, S., Fang, Q., 2004. Diversity of the ovine DQA2 gene. J. Anim Sci, 82 (6): 1553-1563.

Janeway, C.A. Jr., Travers, P., Walport, M., 2001. Immunobiology: The Immune System in Health and Disease. 5th edition. New York: Garland Science.

Kearsey, M. J., 1998. The principles of QTL analysis (a minimal mathematics approach). Journal of Experimental Botany 49, 1619-1623.

Kennan, R. M., Dhungyel, O. P., Whittington, R. J., Egerton, J. R., Rood, J. I., 2001. The type IV fimbrial subunit gene (fimA) of Dichelobacter nodosus is essential for virulence, protease secretion, and natural competence. J. Bacteriol. 183:4451-4458.

Kennan, R. M., Han, X., Porter, C.J., Rood, J.I., 2011. The pathogenesis of ovine footrot. Vet Microb., 153, 59-66.

Laing, E.A., Egerton, J.R., 1981. Some aspects of B. nodosus infection in cattle, in: Ovine Footrot, Report of a Workshop, University of Sydney. 
Lewis, R.D., Meyer, H.H., Gradin, J.L., Smith, A.W., 1988. Effectiveness of vaccination in controlling ovine footrot. J. Anim Sci, 67: 1160-1166.

Litchfield A.M., Raadsma H.W., Hulme D.J., Brown S.C., Nicholas F.W., Egerton J.R., 1993. Disease resistance in Merino sheep. II. RFLPs in Class $2 \mathrm{MHC}$ and their association with footrot. J of Animal Breeding and Genetics. 110 (5): 321-334.

Litinskiy, M.B., Nardelli, B., Hilbert, D.M., He, B., Schaffer, A., Casali, P., Cerutti, A., 2002. DCs induce CD40-independent immunoglobulin class switching through BLyS and APRIL. Nat. Immunol. 3, 822-829.

Lynch, M., \& Walsh, B., 1998. Genetics and Analysis of Quantitative Traits Sunderland, MA, Sinauer.

Maes, M., Hendriks, D., Van Gastel, A., Demedts, P., Wauters, A., Neels, H., Janca, A., Scharpé, S., 1997. Effects of psychological stress on serum immunoglobulin, complement and acute phase protein concentrations in normal volunteers. Psychoneuroendocrinology. 22(6):397-409.

Marshal, D.J., Walker, R. I., Cullis, B. R. \&Luff, M.F., 1991. The effect of footrot on body weight and wool growth of sheep. Australian Vet J, 68, 45-9.

Miles, C., Wayne, M., 2008. Quantitative trait locus (QTL) analysis. Nature Education 1(1): 208.

Miyagi, M., Aoyama, H., Morishita, M., Iwamoto, Y., 1992. Effects of sex hormones on chemotaxis of human peripheral polymorphonuclear leukocytes and monocytes. J Periodontol; 63:28-32.

Myers,G.S., Parker, D., Al-Hasani, K., Kennan, R.M., Seemann, T., Ren, Q., Badger, J.H., Selengut, J.D., Deboy, R.T., Tettelin, H., Boyce, J.D., McCarl, V.P., Han, X., Nelson, W.C., Madupu, R., Mohamoud, Y., Holley, T., Fedorova, N., Khouri, H., Bottomley, S.P., Whittington, R.J., Adler, B., Songer, J.G., Rood, J.I., Paulsen, I.T., 2007. Genome sequence and identification of candidate vaccine antigens from the animal pathogen Dichelobacternodosus. Nat. Biotechnol., 25, 569-575.

Neimann - Sorensen, A., Robertson, A., 1961. The associationbetween blood groups and several production charactersin three Danish cattle breeds. Acta Agric. Scand. 11: 163196. 
Nieuwhof, G.J., Bishop, S.C., 2005. Costs of the major endemic diseases of sheep in Great Britain and the potential benefits of reduction in disease impacts. Anim. Sci., 81, pp. 57-67.

Nieuwhof, G.J., Conington, J., Bishop, S.C., 2009. A genetic epidemiological model to describe resistance to an endemic bacterial disease in livestock: application to footrot in sheep, Genetics Selection Evolution, 41:19.

Ovaere, .P, Lippens, S., Vandenabeele, P., Declercq, W., 2009. The emerging roles of serine protease cascades in the epidermis. Trends in Biochemical Sciences, 34 (9): 453463.

Palmer, M.A., 1993. A gelatin test to detect activity and stability of protease produced by Dichelobacter (bacterioedes) nodosus. Vet Microb, 36: 113-122.

Parham, P., 2009, The Immune System, Garland Science, 2nd edition.

Parker, C.T., Cross, R.T., Hamilton, K.L., 1983. Selection for footrot resistance in Targhee sheep. J. Anim Sci, 62: 164.

Pasquier, B., Launay, .P, Kanamaru, Y., Moura, .IC., Pfirsch, S., Ruffié, C., Hénin, D., Benhamou, M., Pretolani, M., Blank, U., Monteiro, R.C., 2005. Identification of FcaRI as an inhibitory receptor that controls inflammation: dual role of FcRgy ITAM . Immunity $22,31-42$.

Patterson, R. G., Patterson, H.M., 1989. A practical approach to breeding for footrot resistant Merinos. Journal of the New Zealand Mountain Lands Institute, 64-75.

Raadsma, H.W., 2000. Genetic aspects of resistance to ovine footrot. R.F.E. Axford, S.C. Bishop, F.W. Nicholas, J.B. Owen (Eds.), Breeding for Disease Resistance in Farm Animals (second ed.), CABI Publishing, Wallingford, UK, 214-219.

Raadsma, H. W., Dhungyel, O. P., 2013. A review of footrot in sheep: New approaches for control of virulent footrot. Livestock Science, Vol. 156 Issue 1-3, 115-125.

Raadsma, H.W., Egerton J.R., Wood, D., Kristo, C., Nicholas, F.W., 1994a. Disease resistance in Merino sheep.III. Genetic variation in resistance following challenge and subsequent vaccination with a homologous rDNA pilus vaccine. Journal of Animal Breeding and Genetics 111 (5-6): 367-390.

Raadsma, H.W., O'Meara, T.J., Egerton, J.R., Lehrbach, P.R., Schwartzkoff, C.L., 1994b. Protective antibodies and antigenic competition in multivalent Dichelobacter nodosus 
fimbrial vaccines using characterized rDNA fimbrial antigens. Vet Immunolmmunopath, 40: 253-274.

Ribaut, J.M., William, H.M., Khairallah, M., Worland, A.J., Hoisington, D., 2001. Genetic basis of physiological traits. In Application of Physiology in Wheat Breeding, CIMMYT, Mexico.

Ribaut, J.M. and Hoisington, D. A., 1998. Marker assisted selection: new tools and strategies. Trends Plant Sci., 3, 236-239.

Roberts, D.S., Egerton, J.R., 1969. The etiology and pathogenesis of ovine footrot. II. The pathogenic association of Fusiformis nodosus and F. necrophorus. Journal of Comparative Pathology 79, 217-227.

Robinson, J. P., Babcock, G. F., 1998. Phagocyte Function - A guide for research and clinical evaluation. New York: Wiley-Liss, 187.

Rood, J. I., 2002. Genomic islands of Dichelobacter nodosus. Curr. Top. Microbiol. Immunol. 264:47-60.

Sacket, D.M., Abbot, K.A., Jephcott, S., Barber, M., 2006. Assessing the Economic Cost of Endemic Disease on the Profitability of Australian Beef Cattle and Sheep. Meat and Livestock Australia, Sydney.

Sanchez, A., Reeser, J. L., Lau, H. S., Yahiku, P. Y., Willard, R. E., McMillan, P. J., Cho, S. Y., Magie, A. R., Register, U. D., 1973. Role of sugars in human neutrophilic phagocytosis. The American Journal of Clinical Nutrition 26: 1180-1184.

Scapini, P., Nardelli, B., Nadali, G., Calzetti, F., Pizzolo,G., Montecucco, C., Cassatella, M.A.,2003. G-CSF-stimulated neutrophils are a prominent source of functional BLyS. J. Exp. Med. 197, 297-302.

Schneider, P., MacKay, F., Steiner, V., Hofmann, K., Bodmer, J.L., Holler, N., Ambrose, C., Lawton, P., Bixler, S., Acha-Orbea, H., Valmori, D., Romero, P., Werner-Favre, C., Zubler, R.H,, Browning, J.L., Tschopp, J., 1999. BAFF, a novel ligand of the tumor necrosis factor family, stimulates B cell growth. J. Exp. Med. 189, 1747-1756.

Schwaiger, F. W., Gostomski, D., Stear, M. J., Duncan, J. L., McKellar, Q. A., Epplen, J. T., Buitkamp, J., 1995. An ovine major histocompatibility complex DRB1 allele is associated with low faecal egg counts following natural predominantly Ostertagiacircumcincta infection. International Journal for Parasitology 25, 815-822. 
Scott, P. C., Choi, C. L., and Brandon, M. R., 1987. Genetic organization of the ovine MHC class II region. Immunogenetics 25:116-122.

Sisson, S., Grossman, J. and Getty, R., 1975. The anatomy of domestic animals. Vol 1, Edited by CE Rosenbaum.n.n. Ghoshal and D Hillmann., 5th ed, W.B.Saunders company, Philadelphia, USA, PP: 752-755,762.

Skerman, T.M., 1985. In: Footrot in ruminants (Eds Stewart, D.J., Peterson, J.E., McKern, N.M. and Emery, D.L.). Proceedings of a workshop, Melbourne, 77-78.

Skerman, T.M., Erasmuson, S.K., Morrison, L.M., 1982. Duration of resistance to experimental footrot infection in Romney and Merino sheep vaccinated with Bacteriodesnodosus oil adjuvant vaccine. New Zealand Veterinary Journal 30: 27-31.

Skerman, T.M., Johnson, D.L., Kane, D.W., Clarke, J.N., 1988. Clinical footscald and footrot in a New Zealand Romney flock; phenotypic and genetic parameters. Australian Journal of Agricultural Research 39: 907-916.

Skerman, T.M., Moorhouse, S.R., 1987. Broomfield Corriedales: a strain of sheep selectively bred for resistance to footrot. New Zealand Veterinary Journal 35: 101-106.

Smith, C., 1967. Improvement of metric traits through specific genetic loci. Anim. Prod. 9: 349-358.

Soehnlein, O., Lindbom, L., 2010. Phagocyte partnership during the onset and resolution of inflammation. Nature Rev. Immunol. 10, 427-439.

Sousa, P., Froufe, E., Harris, D.J., Alves, P.C. \&Meijden, A., van der. 2011. Genetic diversity of MaghrebianHottentotta (Scorpiones: Buthidae) scorpions based on CO1: new insights on the genus phylogeny and distribution. African Invertebrates 52 (1).

Stear, M. J., Bairden, K., McKellar, Q. A., Scott, I., Strain, S. A. J., 1999. The relationship between the number and size of nematodes in the abomasum and the concentration of pepsinogen in ovine plasma. Research in Veterinary Science 67, 89-92.

Stear, M. J., Eckersall, P. D., Graham, P. A., McKellar, Q. A., Mitchell, S., Bishop, S. C., 2001.Fructosamine concentration and resistance to natural, predominantly Teladorsagia circumcinctainfection. Parasitology 123, 211-218.

Stear, M. J., Henderson, N. G., Kerr, A., McKellar, Q. A., Mitchell, S., Seeley, C., Bishop, S. C., 2002. Eosinophilia as a marker of resistance to Teladorsagia circumcincta in Scottish Blackface lambs parasitology 124, 553-560. 
Stear, M.J., Innocent, G.T., Buitkamp, J., 2005. The evolution and maintenance of polymorphism in the major histocompatibility complex veterinary immunology and immunopathology, 108, 1-2, 53-57.

Stewart, D.J., 1989. Footrot of sheep. In footrot and Foot Abscess of Ruminants, 5-45, eds J. R. Egerton,W. K. Yong and G. G. Riffkin, Boca Raton: CRC Press.

Stewart, D.J., Clark, B. L. \& Jarret, R. G., 1984. Differences between strains of Bacteroides nodosus in their effects on the severity of footrot, bodyweight and wool growth in Merino sheep. Australian Vet J, 61, 349-52.

Stewart, D. J., Clark, B. L., Peterson, J. E., Griffiths, D. A., Smith, E. F., 1982. Importance of pilus-associated antigen in Bacteroides nodosus vaccines. Res. Vet. Sci. 32:140-147.

Stewart, D.J., Emery, D.W., Clark, B.L., Peterson, J.E., Lyer, H., Jarrett, R.G., 1985.

Differences between breeds of sheep in their response to Bacteroides nodosus vaccines. Australian Vet J, 62: 116-120.

Stewart, D.J., Peterson, J.E. Vaughan, J.A. Clark, B.L. Emery, D.L. Caldwell, J.B. Kortt, A.A., 1986. The pathogenicity and cultural characteristics of virulent, intermediate and benign strains of Bacteroidesnodosus causing ovine footrot. Aust. Vet. J., 63, 317-326.

Strain, S. A. J., Bishop, S. C., Henderson, N. G., Kerr, A., McKellar, Q. A., Mitchell, S. Stear, M. J., 2002. The genetic control of IgA activity against Teladorsagia circumcincta and its association with parasite resistance in naturally infected sheep parasitology 124, 545552.

The Merck Veterinary Manual ( Marie S. Bulgin, Editor), 2013. 10th ed., published by Merck \& Co., Inc. and Merial Limited.

Thomas, J.H., 1957. The eradication of contagious footrot of sheep. Australian Vet J, 33, 263-266.

Thompson, C.B., 1995. Apoptosis in the pathogenesis and treatment of disease. Science 267(5203): 1456-62.

Todar, K., 2008. Todar's Online Textbook of Bacteriology. http://www.textbookof bacteriology.net/

Tsuboi, N., Asano, K., Lauterbach, M., Mayadas, T.N., 2008. Human neutrophil Fcy receptors initiate and play specialized non-redundant roles in antibody-mediated inflammatory diseases. Immunity $28,833-846$. 
Turner, A.K., Begon, M., Jackson, J.A., Bradley, J.E., Paterson, S., 2011. Genetic Diversity in Cytokines Associated with Immune Variation and Resistance to Multiple Pathogens in a Natural Rodent Population. Plos Genetics, Vol 7, 10: 1-11.

Vignal, A., Milan, D., SanCristobal, M., Eggen, A., 2002. A review on SNP and other types of molecular markers and their use in animal genetics. Genetics Selection Evolution 34, 275-305.

Wani, S.A., Samanta, I., 2005. Current understanding of the etiology and laboratory diagnosis of footrot. Vet J. Vol 171,(3) 421-428.

Wheater, P.R., Stevens, A., 2002. Wheater's basic histopathology: a color atlas and text. Edinburgh: Churchill Livingstone.

Whitacre, C.C., Reingold, S.C., O'Looney, P.A., 1999. A gender gap in autoimmunity. Science;283:1277-8.

Woolaston, R.R., 1993. Factors affecting the prevalence and severity of footrot in a Merino flock selected for resistance to Haemonchuscontortus. Australian Veterinary Journal, 70, 365-369.

Wu, S.A., Yeh, K.W., Lee, W.I., Yao, T.C., Kuo, M.L., Huang, B., Huang, J.L., 2013. Impaired phagocytosis and susceptibility to infection in pediatric-onset systemic lupus erythematosus. Lupus 22 (3), 279-288.

Wuliji, T., 2011. Establishing a footrot resistant sheep flock by phenotypic and genetic marker assisted selection, USDA Evans-Allen grant.

Wuliji, T., Hickford, J.G.H., Lamberson, W., Shanks, B., Azarpajouh, S., 2014. Ovine footrot gene marker screening in a Katahdin sheep flock. J. Anim. Sci. Vol. 92 E-Suppl. 2/J. P.933.

Wuliji, T., Hickford, JGH., Shanks, B., Lamberson, W., Zhou, H., Azarpajouh, S., 2013a. Establishing a footrot resistant sheep flock by footrot gene marker test screening. In 'Lameness in Ruminants' (Ed. Becky Whay and Jo Hockenhull), Bristol, UK. P. 72-73.

Wuliji, T., Lamberson, W., Shanks, B., Caldwell, J., Clifford-Rathert, C., Pennington, J., Swartz, H., Azarpajouh, S., 2013b. Genetic marker assisted selection for footrot disease resistance in sheep flocks. J. Anim. Sci. Vol. 91, E-Suppl. 2. P. 606-607.

Zucker-Franklin, D., Grossi, C.E., 2003. Atlas of blood cells: function and pathology Milano: Edi. Ermes, 174. 
Zwietering, M.H., Jongenburger, I., Rombouts, F.M., van't Riet, K., 1990. Modeling of the Bacterial Growth Curve. Appl. Environ. Microbiol. Vol 56,(6) 1875-1881. 
VITA

Samaneh Azarpajouh was born May 13, 1984 in Esfahan, Iran. After attending high school in Esfahan, Samaneh entered Shahrekord College of Veterinary Medicine in Shahrekord, Iran in 2002 and graduated with honors as top researcher with Doctor of Veterinary Medical (DVM) degree in 2008. She worked in Arian Dam Sanat Co, Esfahan, Iran, served as Laboratory Assistant Technician and Technical Manager of Veterinary Pharmacy in 2009. While employed at the Lincoln University of Missouri as a Graduate Research Assistant, she completed the coursework towards her PhD in University of Missouri-Columbia (2014). 